\title{
From the Tombs into the City: Grave Robbing and the Reuse of Funerary Spolia in Late Antique Italy
}

\begin{abstract}
Archaeological evidence demonstrates that funerary spolia (e.g. sarcophagus lids, funerary altars, epitaphs, reliefs and statues) were frequently reused to decorate the interiors of public and private buildings from the third to the sixth century. Therefore, the marble revetments of high imperial tombs must have been spoliated. Imperial edicts, which tried to stamp out the overly common practice of tomb plundering, confirm that the social practice of tomb plundering must have been far more frequent in late antiquity than in previous periods. This paper discusses the reuse of funerary spolia in private and public buildings from Latium and Campania and contextualises them by examining legal sources addressing tomb violation. Furthermore, this study considers the extent to which the social practice of tomb plundering and the reuse of funerary material in late antiquity can be connected with larger urbanistic, sociohistorical, and political transformations of Italian cityscapes from the third to the sixth century. ${ }^{1}$
\end{abstract}

\section{Introduction}

Roman funerary art was a very common form of spolia in medieval Italy. It was visibly reused within walls, houses, and in the facades of Romanesque churches, and sometimes even prominently incorporated into the interior decoration of churches. ${ }^{2}$ For example, Roman cinerary urns, funerary altars or sarcophagi were frequently repurposed to serve as holy water or baptismal fonts (FIG. 1). Numerous art historical studies have discussed the ideological meaning and historical implications of these funerary spolia within their new Christian contexts. ${ }^{3}$ Far less attention has been paid to the reuse of funerary material in the construction and decoration of late antique buildings. This imbalance is partly due to the fact that the large amount of funerary material found within late antique city centres is generally examined in connec-

\footnotetext{
${ }^{1}$ This paper is based on talks I gave in Rome and Oxford and on some results of my forthcoming Habilitationsschrift: "Transforming the Past: Plundering and reusing tomb material in late antique and early medieval Italy (Berlin 2019)". Furthermore, I would like to thank Tim Penn and Ginny Wheeler for helpful comments.

${ }^{2}$ Esch 2005, 51.

${ }^{3}$ On the reuse of funerary spolia in medieval building in Italy (especially from the $9^{\text {th }}$ to the $13^{\text {th }}$ century), see Esch 2005 ; Esch 2011; Fabricius Hansen 2013; Jäggi 2013; Fabricius Hansen 2015; Antonelli et al. 2016. On the frequent medieval reuse of sarcophagi, see Settis, Andreae 1984; Koch 1994; Messina 2005; Verkerk 2007; Cartron, Fabrice Scuiller 2015; Huskinson 2015, 255-274.
} 
tion with the city's medieval afterlife and thus interpreted as having been transferred into the city merely as the result of medieval construction or lime production. ${ }^{4}$ The reassessment of several find contexts, especially from Latium and Campania, demonstrates that, already from the third and especially during the fourth and fifth centuries, marble revetments were spoliated from tombs. From there the material was transported into cities in order to be reused within buildings both of a functional (i.e streets, city walls, defensive systems) and representative nature (such as domus, villas and several public buildings). ${ }^{5}$ Several fourth-century legal sources also confirm that imperial tombs that had fallen into neglect were the target of organised grave robbing. A comparison of legal and archaeological data allows for the reinterpretation of find contexts from private and public buildings and provides new insight into the common social practice of tomb robbing in late antiquity - in which even the imperial authorities themselves may have played a part. ${ }^{6}$

\section{Grave robbing in the legal sources}

When discussing grave robbing, it is important to note that it is always a matter of perspective who is deemed a grave robber and what is considered plundering or robbing. This consideration is well explained by two historical illustrations from the late $18^{\text {th }}$ and mid $19^{\text {th }}$ century respectively. Both images show individuals removing grave goods from ancient tombs. However, one shows a learned, elegantly dressed collector (FIG. 2), and the other depicts poor and scruffy-looking tomb hunters (FIG. 3). During archaeological excavations, tombs are emptied and grave goods are taken away and put into secondary use in museums, yet we would not call archaeologists grave robbers. In short, the generally negative connotations surrounding the act of robbing tombs are partly the result of a modernist scholarly perspective. ${ }^{7}$

Plundering ancient or sometimes even contemporary tombs was a common phenomenon throughout antiquity. It is well attested in Egyptian and Babylonian kingdoms and remained very frequent in post-antique periods. ${ }^{8}$ For ancient Greece and Rome, beyond the ample material evidence, several legal sources inform us to what extent it was common practice. ${ }^{9}$ On Roman funerary epitaphs, the very frequent inclusion of $D M$ (dis manibus) reminded the living that the tombs were protected by sacral laws and that their grave goods were dedicated to the manes. Thus, as res religiosae removed from the living, the grave goods could no longer be possessed by mortals. ${ }^{10}$ Depending on the circumstances and on the social rank of the perpetrator, the act of grave robbing was considered a serious form of sacrilege and could

\footnotetext{
${ }^{4}$ See for example Lenzi 1998; Munro 2016; Porcari 2009.

${ }^{5}$ For example in the city wall of Verona, see Esch 2005, 78 fig. 3; Ward-Perkins 1984, 192. For the city wall of Pula, see Girardi Jurkić 2011, 23-28.

${ }^{6}$ For a similar approach, see Bolla 2015, 357-378 and Tantillo, La Rocca 2017.

${ }^{7}$ On the different levels of meaning of grave robbing/looting/plundering: Kümmel 2009, 19-26.

${ }^{8}$ For an overview of the practice of tomb plundering in ancient cultures, see Jankuhn 1978; Kümmel 2009; Schnapp 2011, 163-186; Lamm 2015. For Merovingian grave plundering, see Klevnäs 2013.

${ }^{9}$ Tomb violators (tymborychia) are already mentioned in Aristophanes, Frogs (1149) and also in the XII tables (Cicero leg. 2. 26), the destruction of tombs was punished. Crawford 1996, 582.

10 "In the archaic period, tombs and the bodies they held, were protected both by religious and civil laws." Rebillard 2009, 58. On the iura sepulchrorum, see Kaser 1978, 16; Volp 2002, 88 f.
} 
be severely punished. ${ }^{11}$ During the Principate, this felony could even be punishable by death depending on the social standing of the tomb violator. ${ }^{12}$ But there were always exceptions, and the situation seems to have been very different when in relation to the tombs of Rome's enemies. A passage in Strabo Book VIII on the recolonization of Corinth illustrates this double standard quite explicitly:

"Corinth remained a long time deserted, till at length it was restored on account of its natural advantages by divus Caesar, who sent colonists thither, who consisted, for the most part, of the descendants of free-men. On moving the ruins, and digging open the sepulchres, an abundance of works in pottery with figures on them, and many in brass, were found. The workmanship was admired, and all the sepulchres were examined with the greatest care. Thus was obtained a large quantity of things, which were disposed of at a great price, and Rome filled with Necro-Corinthia, by which name were distinguished the articles taken out of the sepulchres, and particularly the pottery. "13

Most of the laws against tomb violations are compiled under the title de sepulchris violatis in the Codex Theodosianus (9.17.1-7) and the Codex Iustinianus (9.17.1-5). ${ }^{14}$ Other legal texts or concerns on tomb violations are preserved in the Pauli Sententiae, the edictum Theodeorici, the leges Visigothorum, and in Cassiodorus' Variae. ${ }^{15}$ On the basis of these sources, several Roman law specialists have noted that plundering tombs in order to obtain grave goods was a common occurrence, but only became a very frequent act from the third century onwards. $^{16}$

Three important observations concerning when, and why tomb violations took place can be gained from legal sources. Firstly, in the middle of the fourth century, several imperial edicts - most of them promulgated by the emperors Constantius II and Julian - tried to stamp out what had become an all too frequent practice of privately organised tomb plundering. Secondly, the laws (CTh 9.17. 1-5) explicitly protected the marble elements, including the columns, statues, precious stones and ornaments belonging to tombs. ${ }^{17}$ Lastly, two edicts (CTh 9.17.2 and 9.17.5) inform us which public and private buildings, and even in which rooms, marble funerary material was to be reused. The first of the two edicts (CTh 9.17.1) was promulgated in $340 \mathrm{AD}$ in Milan by Constantius II to Titianus, the prefect of Rome:

\footnotetext{
${ }^{11}$ Spoliation of tomb decoration is just one of different forms that were considered as grave sacrilege "Grabfrevel", see Behrends 1978, 85.

${ }^{12}$ Behrends 1978, 105f.

${ }^{13}$ Strabo, VIII, 6.23. Translation by: Hamilton, Falconer 1856, 65. For further references on Corinthian artworks reused in Roman houses (also mentioned in Hor. sat. 2,3,20-26 and in Cic. parad. 1,13; V, 37), see Cantino Wataghin 1986, $173-$ 178; Azzara 2002, 1-12. A similar event took place in Capua, again under Caesar, when houses and villas were built on top of a very old cemetery and precious grave goods like vases and bronze artefacts were found and exposed: Suetonius, Caes. 81.

${ }^{14}$ Kaser 1978, 15-17; Klingenberg 1983, 595-600; Strothmann 2006, 1-9. The edicts from the Codex Iustinianus (CI 9.17.2-5) are in major parts repetition of the edicts already mentioned in the Codex Theodosianus (CTh 9.17.1-5).

${ }^{15}$ Pauly sententiae 1.21; Edictum Theodorici 54 and 110; Leges Visigothorum 11.2.1-2; Cassiod. Var. 3.19; 4.18; 4.34; $6.8,4$.

${ }^{16}$ This is further reflected in epigraphical sources: Mommsen 1899, 809-821; Mommsen 1895, 212-220; Creaghan 1951, 2f.; Kaser 1978, 86; Rebillard 2009, 62; Bolla 2015.

${ }^{17}$ Relics are explicitly protected in laws from the end of the fourth onwards (CTh 9.17.7): Rebillard 2003, 47-55; Rebillard 2009, 70-71; Lafferty 2014, 249-279.
} 
"If anyone should be apprehended in the act of demolishing a tomb, if he should do this without the knowledge of his master, he is to be sentenced to the mines. If, however, he should be urged by the authority and command of his master, he is to be punished by relegation. And if by chance anything taken from the tombs and carried to his house or villa should be discovered after the issuance of this law, the villa or house or any other building is to be vindicated to the account of the fiscus. "18

The second edict (CTh 9.17.5) was promulgated in 363 AD by Julian and was addressed to the people of Antioch and where it is mentioned: "Sed et ornamenta quidam tricliniis aut porticibus auferunt de sepulchris". It informs us that ornaments were taken from the tombs to reuse them in porticoes and triclinia.

\section{Late antique reuse of funerary spolia in Latium and Campania}

In Latium and Campania, the reuse of funerary material from the third to the sixth century was a very widespread phenomenon: imperial funerary epitaphs were reused for floor pavements, sarcophagi were transformed into fountains, and funerary statues even served as ornamenta for the interior decoration of private and public buildings. Selected find contexts from Monte Gelato, Ostia, Teanum, Viterbo, and Rome illustrate the broad spectrum of reuse.

\section{Mola di Monte Gelato}

Between 1986 and 1990, large-scale excavation took place on the Mola di Monte Gelato, which lies 34 kilometres to the north of the centre of Rome. Investigations uncovered structures spanning from the Augustan period to the $12^{\text {th }}$ century AD. ${ }^{19}$ The excavators divided the archaeological findings into six main occupation phases. A fairly elaborate villa with a porticoed courtyard/peristyle extending to the east was built during the early imperial period, which then underwent at least two rebuilding phases during the high and late imperial periods (FIG. 4; phases 1-3). ${ }^{20}$ The apsidal room to the south was assigned as part of the mid-fourth century refurbishment (FIG. 4; phase 3) and was interpreted - on account of its apsidal form as a very early church building. However, nothing other than the apse supports this hypothesis, and the recovery of a graffito of a cross on a potsherd provides little further corroboration. ${ }^{21}$ Sometime between the end of the fifth and the sixth century, an enormous lime kiln was built next to this apsidal hall (FIG. 4; phase 4). A church building was built in the $10^{\text {th }}$ century on top of the apsidal hall, after which a cemetery developed around this church until the $12^{\text {th }}$ century (FIG. 4; phases 5-6).

In addition to ceramic finds and coins, the excavations also uncovered sculptural and architectural elements, most of which were found in late imperial layers and included reused

\footnotetext{
${ }^{18} \mathrm{CTh}$ 9.17.1: ...et si forte detractum aliquid de sepulchris ad domum eius villamque pervectum post hanc legem repperietur, villa sive domus aut aedificium quodcumque erit fisci viribus vindicetur. Translation by C. Pharr (Pharr 1952) 239.

${ }^{19}$ Potter, King 1988, 253-311; Potter et al. 1997.

${ }^{20}$ Between the end of the first and the second century AD, a small private bath building was built at the western entrance and a funerary monument was built on the opposite road: Potter et al. 1997, 35-42.

${ }^{21}$ Potter, King 1988, 271, 279 no. 3.2 fig. 14.2; Potter et al. 1997, 71. 75-77.
} 
funerary material and, above all, funerary inscriptions. ${ }^{22}$ The presence of this funerary material was explained in connection with the lime kiln, where just one, almost complete funerary relief was found. ${ }^{23}$ However, almost all of the epigraphic fragments, sculptures, and pieces of architectural veneer hailing from funerary contexts were found distributed within different layers spread across the compound, most of them in late imperial layers (FIG. 5). One might therefore suggest that the funerary material might have been brought there and reused within the late antique villa compound before the lime kiln was built. This hypothesis is strengthened by the fact that half of this funerary material was made out of tufa, which could not be used for lime burning. ${ }^{24}$ In light of this evidence, it is furthermore debatable whether the midfourth-century apsidal hall should be interpreted as a church. Because of its form, it could equally have been be a typical late antique apsidal dining hall. Accordingly, the kiln may simply have been constructed next to it because most of the marble revetments of this late antique apsidal hall were burned for lime, including the floor, which was found to have been completely stripped of its marble pavement. ${ }^{25}$

\section{Ostia}

The extensive spoliation of marble fittings from abandoned buildings in Ostia indicates that reusing marble from older buildings to embellish new buildings in late antiquity was common practice. ${ }^{26}$ The strikingly high number of imperial epitaphs reused in late antique houses and bath buildings does give the impression that funerary material in particular was considered a very welcomed building material in late antique embellishments (FIG. 6). ${ }^{27}$

Giovanni Becatti, who studied the floor pavements of the late antique houses in Ostia, pointed out how frequently funerary inscriptions were integrated into the floors of many domus. Sometimes several marble epitaphs from the same family grave were reused in the same house, such as in the Domus delle Colonne (Reg. IV, III, 1), where the inscriptions of the funerary monument of the gens Baebia were visibly integrated in the opus sectile flooring. ${ }^{28}$ In the case of the Domus del Protiro (Reg.V, II, 4-5), which underwent larger transformations between the middle of the third and the early fourth century, several marble epitaphs were reused in highly visible spots in the late antique floor paving as was reused statuary from different public buildings (i.e. temples). ${ }^{29}$ Right in front of the vestibule, greeting every visitor, an epitaph (sibi et suis is clearly visible) was reused as the lid for a drainage pit (FIG. 7). In the high quality, early-fourth-century opus sectile floor of the cubiculum next to the tri-

\footnotetext{
${ }^{22}$ Potter et al. 1997, 207-232.

${ }^{23}$ Munro 2016, 83-85.

${ }^{24}$ In total seven inscription on blocks or fragments (sarcophagus) were found in the villa, from which five are of funerary provenance and two of them made out of tufa. Potter et al. 1997, 201-216 Nr. 1-7.

${ }^{25}$ Potter et al. 1997, 64-71.

${ }^{26}$ Pensabene 2007, Gering 2011a.

${ }^{27}$ Already Wickert 1933, 821f. observed that a large quantity of grave inscriptions and sarcophagus fragments came from the city centre of Ostia. The reuse of funerary slabs in the floor paving of late antique domus had been studied in detail already by Becatti 1948; Becatti 1961; see also Murer 2016, 178.

${ }^{28}$ Becatti 1948, 200.

${ }^{29}$ Boersma 1985, 291-294; Pavolini 2013, 158; Pensabene 2007, tab. 149. arachne.dainst.org/entity/3751983 (Danner 2017).
} 
clinium, a funerary inscription was incorporated into one of the central pieces; although the D from the abbreviation D. M. was either erased or on another part of the funerary epitaph. ${ }^{30}$

Funerary inscriptions were also reused to embellish the late antique Domus dei Pesci (Reg. IV, III,3), which was refurbished in the fourth century. A funerary slab was inserted in the basin of the pyramidal stepped fountain in the central courtyard of the domus, which every visitor would have passed (FIG. 8 ). ${ }^{31}$

In the so-called Sede degli Augustali (Reg. V, VII, 1-3, 5), another late antique domus, ${ }^{32}$ sarcophagus lids were reused for door lintels and windowsill fittings. ${ }^{33}$ Next to other funerary statues found within the same domus, a reclining nymph belonging to the lid of a klinê sarcophagus was reused as fountain figure. ${ }^{34}$

In addition to its considerable reuse in private contexts, funerary material was integrated into public buildings. This practice is visible in several bath buildings, including the Terme dei Cisiarii (Reg. II, II, 3), the Terme del Foro (Reg. I, XII, 6), the Terme di Nettuno (Reg. II, IV, 2) and the Terme del Sileno (Reg. IV, IX, 7). ${ }^{35}$ Funerary material is also present in late antique nymphaea (i.e. the Ninfeo degli Eroti, Reg. IV, IV, 1) and in public latrines. ${ }^{36}$ In the so-called Forum latrine, which underwent substantial refurbishments in the late fourth century, a sarcophagus relief was reused as one of the latrine benches (FIG. 9). ${ }^{37}$

These finds clearly show that tombs in the necropolis of Ostia must have been plundered not only in the Middle Ages, ${ }^{38}$ but already at some point during late antiquity. ${ }^{39}$ Numerous questions thus arise: how was this plundering possible, and who was responsible? Was it the work of individuals who stole the material in the dead of night, or was the spoliation of tombs more organized?

One of the main reasons for more easily disposable funerary material from the middle of the third century onwards might have been the shift of demographics in early third-century Ostia. Many older families disappeared, their tombs fell into oblivion and were no longer protected from plundering. ${ }^{40}$ This may explain why, during the early third century, many of the second-century temple tombs in the Isola Sacra necropolis that were positioned directly along the road from Ostia to Portus were removed to make space for new third-century tombs in such a highly visible location. ${ }^{41}$ Since funerary sculpture also formed an integral part of decorations in public buildings - at least from the fourth century onwards - its reuse must

\footnotetext{
30 (Inv. no. 19888) Boersma 1985, 291-294 no. 2. Also lines 2-5 of the inscription on a white marble slab (Inv. no. 19887) that was reused as a foot-plinth for the latrine of the same domus were erased. Boersma 1985, 291-294 no. 5.

${ }^{31}$ Pavolini 2013, 147-160 fig. 10; Carroll 2006, 84, fig. 28; arachne.dainst.org/entity/3751988 (Danner 2017).

${ }^{32}$ Pavolini 2011.

${ }^{33}$ Laird 2000, 41-84, 52.

${ }^{34}$ On the re-use of funerary statues in late antique domus (especially in the so-called Sede degli Augustali and the Aula di Marte e Venere), see: Murer 2016.

${ }^{35}$ Terme dei Cisiarii: Murer 2016, 190-192 ill. 8; Terme del Foro: Pensabene 2007; Marinucci 2012, 11 no. 4; Terme del Sileno: David 2013, 173-186.

${ }^{36}$ Calza 1978, 59 no. 74, pl. 56 fig. 74; Schmölder-Veit 2000.

${ }^{37}$ Underwood 2015, 393-394 ill. 7.

${ }^{38}$ Greenhalgh 1989, 101-102.

${ }^{39}$ The late antique reuse of these funerary sculptures partially explains why most of the high imperial tombs from the cemeteries at Ostia were found completely bereft of their sculptural decorations. Heinzelmann 2000, 77-84, 120.

${ }^{40}$ Gering 2011b, 301-315.

${ }^{41}$ Calza G. 1940, 307-308; Baldassarre 1988; Carroll 2006, 83; Borg 2013, 23-30, 155-158.
} 
have been a more organised phenomenon, perhaps even led by official authorities. ${ }^{42}$ Literary sources confirm the reuse of funerary material by official authorities at the end of the fourth century, although not specifically in Italy. For example, in his oration 46, Libanius mentions that a provincial governor reused funerary material to restore a portico for the city of Antioch. ${ }^{43}$ On the other hand, the edict against tomb violations (CTh. 9.17.2) - promulgated by Constantius II in Milan in 349 AD - clearly states that official authorities did the same: "But even if a monument has been torn down by the order of a judge (judex), the penalty may not be avoided under the pretext of erecting public buildings. "44 Therefore, by the middle of the fourth century, the imperial authorities seem to have had to prevent what had become frequent unauthorised tomb plundering. The same edict also states that no punishments were to be exacted if the columns or the marbles from the tombs were reused before this law was issued in $333 \mathrm{AD}^{45}$ Archaeological contexts in Campania, Latium, and even Rome confirm that, by that date, several public buildings were already adorned with funerary spolia.

\section{Teanum Sidicinum}

The Campanian city of Teanum Sidicinum (modern Teano) was located between the via Appia and via Casilina. The Late Republican theatre/temple complex (in località Grotte) is the best preserved of the ancient city's public buildings. ${ }^{46}$ As revealed by recent excavation results and the anastylosis of the scaenae frons,${ }^{47}$ the theatre was completely refurbished in the early third century (FIG. 10). This renovation may have been initiated by the emperor Septimius Severus himself and only completed under Gordianus III since their names are mentioned in the dedicatory inscriptions on the architrave of the scaenae frons. ${ }^{48}$ Next to the newly cut marble architectural décor, several older marble sculptures were reused within the niches of the stage building. ${ }^{49}$ Among these finds was a $1.6 \mathrm{~m}$ high L-shaped relief depicting a man in the guise of a heroic nude of the Hermes Richelieu type (FIG. 11). ${ }^{50}$ To the left of his head is the head of a horse. A servant is standing next to his feet, and on the right, there is a tree trunk on which a snake is curled up. Here a clear cut is visible since this relief is only part of a larger Hellenistic tomb monument. Parallels for such funerary representations are known from many eastern regions. ${ }^{51}$ There are several marks from the metal clamps for its

\footnotetext{
${ }^{42}$ Murer 2016.

${ }^{43}$ Libanius, Or. 46.44. Kunderewicz 1971, 140; Tantillo, La Rocca 2017, 23 n. 14.

44 Translation by Pharr 1952, 239. (C. Pharr suggests translating judex as governor of a province).

45 "If any person, therefore, should take away columns or marble from monuments, only after the time of the consulship of Dalmatius and Zenophilus, of course [i. e. 333 A.D.], he shall pay to the account of the fisc a pound of gold for each tomb thus violated" Translation by Pharr 1952, 239.

${ }^{46}$ Hay Keay, Millett 2012, 105-113.

${ }^{47}$ On the three major building phases (1. late first century B.C., 2. beginning of the third century A.D., 3. post antique period): Sirano, Beste 2006, 401-410; Sirano 2011, 31-38.

${ }^{48}$ Sirano 2011, 33-34.

${ }^{49}$ As a reclining Nile statue, an Aphrodite statue, a statue of Dionysus and a colossal seated statue (probably representing an emperor that stood over the porta Regia): Sirano et al. 2002, 329-330; Sirano, Beste 2006, 410-421; Sirano 2011, 181220.

${ }^{50}$ On the Hermes-Richelieu type, see Maderna 1988, 229-230 no. H6 pl. 28.2.

${ }^{51}$ The relief is made in high quality Proconnesian marble: Sirano, Beste 2006, 404-405; Sirano 2011, 215-216. Further comparisons of such funerary reliefs in type and motif were found in Pergamon from the second century B.C. (Istanbul,
} 
secondary attachments, which led the excavators to conclude that it must have been integrated into the scaenae frons of the Severan theatre, visible for all to see (FIG. 10). ${ }^{52}$ When precisely the Late Hellenistic funerary monument was brought to Italy remains unclear. It may well have already been brought to Italy long before the Severan era since Greek funerary art was not an unusual decoration piece in Late Republican Roman houses. ${ }^{53}$

\section{Viterbo}

Another example of reused funerary sculpture comes from the Terme di Bacucco in Viterbo. The bath structures are very poorly preserved, but, judging from their late masonry, they underwent substantial alterations in the fourth century. ${ }^{54}$ A reclining couple (FIG. 12) of late Severan date was found in an octagonal hall of this bath compound during the early $19^{\text {th }}$ century. Today it is on display in the Louvre (FIG. 13) with the modern addition of a plinth. ${ }^{55}$ The piece does not illustrate the patrons of the bath, as has been argued by several scholars. ${ }^{56}$ Rather, the presence of the river god is the result of a later re-carving: the river god mask was carved into the headrest, and a hole for a lead pipe was inserted into the mouth to serve as a fountain figure for the late antique baths. However, as H. Jucker recognised, it is actually a reused lid of a kline sarcophagus. ${ }^{57}$ The sarcophagus lid must have been transferred to the baths at a later date in a secondary use as a fountain figure.

\section{Rome}

From 1999 to 2001, Roman structures were brought to light next to the Fontana di Trevi, at the intersection of Via San Vincenzo and Vicolo del Puttarello 25 (FIG. 14). They are part of a larger insula complex in the ancient Regio VII (via Lata), which extended to the so-called vicus Caprarius (today Via di San Vincenzo). ${ }^{58}$ During the excavations, early imperial structures of a 'Caseggiato' were uncovered, dating to Neronian period, which had been altered during the Hadrianic era. Over the course of the late third and early fourth century, a late antique domus had been built within these structures, which was abandoned after the Vandal sack of Rome in 455 A.D. ${ }^{59}$ Due to medieval plundering of the site, the decor of this late an-

\footnotetext{
Archaeological Museum inv. no. 362): Pfuhl, Möbius 1977, no. 1477 pl. 214; in Smyrna: Pfuhl, Möbius 1977, no. 158 pl. 35 and in Thessaloniki: Despinēs, Stephanidou-Tiveriou, Voutyras 1997, 74 no. 55 fig. 137. A similar funerary relief is also known from Taranto dating to the fourth century B.C.: Himmelmann 1989, 56-57, fig. 22. Furthermore similar examples (but only with the combination of armour) are known from the late republican period from Rome, see Hallett 2005, 113 pl. 61.

${ }^{52}$ Sirano 2011, 111, 216; Sirano, Beste 2006, 404.

${ }^{53}$ For example, the Greek funerary relief found in the so-called Horti Liciniani: Bell 1998, 295-314.

${ }^{54}$ Colonna 1975; Ganzert 1981; Milioni 2014, 8.

55 (Paris, Louvre Inv. Ma 351) "Non lungi dalla terma, vi sono due collinette artificiali, sotto le quali restano coperte alcune costruzioni architettoniche sepolcrali. Un bel cornicione di pietra è stato intanto scoperto, ma la cella si è trovata già saccheggiata." Camilli 1831, 201-202.

${ }_{56}$ Wrede 1981, 232-233 no. 106; Fejfer 2008, 127; Lo Monaco 2011, 342.

${ }^{57}$ Jucker 1966, 501 fig. 9.

${ }^{58}$ Gatti 1925, 271-304; LTUR 1, s.v. Aedicula caprarius, 17-18; Lanciani 1990, FUR P1. 16. On the late antique domus in Rome, see Guidobaldi 1999, 55; Machado 2012, 137; Guidobaldi 2007, 59.

${ }^{59}$ Insalaco 2005; Machado 2012, 148-149.
} 
tique domus is only preserved fragmentarily. However, several marble slabs were reused for the late antique decoration of the walls and floors, among which were imperial funerary epitaphs. Close to this site, modest late- $19^{\text {th }}$-century excavations recovered a tabula ansata from a sarcophagus lid. According to the published reports, this was inserted into a Late Roman floor. ${ }^{60}$ Among the new finds from the fourth-century layers of this domus was a first-century ash urn and a statue dating to the early first century; according to the excavators, the latter may be a piece of funerary sculpture. ${ }^{61}$ The new excavations also unearthed several funerary epitaphs from the high imperial period, which had been found in situ, reused, next to other marble slabs, for the paving of the stairs (FIG. 15). ${ }^{62}$

Near the discussed finds from this domus, there are several additional find spots in Rome, mainly within other late antique domus, where funerary material (especially funerary epitaphs) was reused in pavements. ${ }^{63}$ But in the case of Rome, it is very difficult to closely date reuse, since funerary material was also commonly reused in the medieval and later periods. ${ }^{64}$

Furthermore, funerary material was also reused in late antique monuments built to honour the emperor. ${ }^{65}$ Inside the Arch of Constantine, two large funerary inscriptions were built into the small staircase leading to the attic of the arch (in its original configuration). As R. Lanciani wrote: 'The inside of the structure also is built with a great variety of materials taken from the tombs of the Fabii and of the Arruntii; the carvings and inscriptions of which are still perfect. ${ }^{, 66}$ The two inscriptions (FIG. 16) were inserted visibly so that one can read the names of the well-known Republican gens Fabia and gens Arruntia, and one might suggest the blocks - although only visible in the interior - may have been selected for their historical importance. A similar case of a probable symbolic reuse of a funerary inscription is known. When the lead roof of the cupola of the Pantheon was unveiled for restoration in 1971, L. Cozza investigated the marble roof tiles at the outer border of the cupola. ${ }^{67}$ One surprising find was a reused Late Republican funerary epitaph among the reused roof tiles (FIG. 17). From the surviving part of the inscriptions, one can deduce that this monument was erected for a woman in the Campus Martius: [---statuam---] /(---] post mortem ponendam cen [suit]/ [sepe]lirique eam in campo martio iu [ssit]. L. Cozza suggested that such honours were only granted to a few women at that time; Julia, daughter of Caesar and wife of Pompey, would be the most plausible candidate. ${ }^{68}$ Her funerary monument must have stood close to the Pantheon and might have been destroyed (or the funerary statue might have been transported to another location) and perhaps reused already in Agrippa's Pantheon. ${ }^{69}$

\footnotetext{
${ }^{60} 30$ x 27 x $10 \mathrm{~cm}$ (Via dell'Lucchesi) Gatti 1925, 273.

${ }^{61}$ Said to be a funerary statue of a girl from the second century A.D.: Insalaco 2005; Machado 2012, 147-148.

${ }^{62}$ Also a $10 \mathrm{~cm}$ long head of a young man (Hadrianic period) once belonging to a sarcophagus relief, had been found. Insalaco 2005, 1-4.

${ }^{63}$ For examples, see Coates-Stephens 2002, 284, 287, 291.

${ }^{64}$ For example in the Crypta Balbi, see Saguì, Coletti 2004.

${ }^{65}$ Also within monuments built by the initiative of emperors like the Aurelian Wall, see Coates-Stephens Robert 2012.

${ }^{66}$ Lanciani 1899, 31. Although part of the attic was reconfigured in the sixteenth century, the two funerary inscriptions belonged to the original structure of the fourth-century arch. What kind of other reused funerary material Lanciani saw is not yet clear. For the inscriptions, see also Pensabene 2015, 104. (I have to thank Tim Penn for this hint).

${ }^{67}$ Cozza 1983, 109-118; Pensabene, Panella 1993-1994, 115.

${ }^{68}$ Cozza 1983, 111-115.

${ }^{69}$ Cozza 1983, 117.
} 
These examples from Rome clearly show that, in addition to the private reuse of funerary material, public monuments, including those erected to honour the emperor, were built with funerary spolia. If we take the example from the Pantheon, the reuse of such material was as early as the Hadrianic period. However, this practice became especially frequent from the end of the third century onwards; in addition to the Aurelian wall, funerary spolia were increasingly incorporated into public buildings in the capital - despite laws that strictly forbade such practices.

\section{Conclusions}

Literary and legal sources, together with archaeological evidence, prove that, as early as the third century, along with spolia from abandoned public buildings and temples, funerary material had become commonly used for redecorating both domestic interiors and public buildings. Although in cities like Rome, because of their continuous afterlife and extensive reuse of funerary spolia for medieval and later building, it remains difficult to grasp the extent of late antique reuse, there are several well-preserved late antique cityscapes such as Ostia, where this reuse can be tracked in much greater detail. The habit must have continued at least until the sixth century; funerary material was incorporated in different public building structures, especially within defensive systems and churches in many regions of the Late Roman empire. ${ }^{70}$ The well-preserved ornaments in the tombs (especially the sarcophagi and statues) were a reason for spoliating earlier tombs of their marble decor. This reuse must have developed from a more private to a more official spoliation of earlier pagan tombs. Correspondingly, the imperial edicts against tomb violation (CTh. 17.9.1-5) discussed in this paper confirm that the primary reason for late antique grave plundering was to obtain marble revetments, though, from the second half of the fourth century, bones reused as the relics of saints also became important. ${ }^{71}$ The motivation ${ }^{72}$ for tomb robbing is therefore best explained by economic motivations, i.e. to obtain building material, rather than as deliberate violations of pagan tombs by Christians. ${ }^{73}$ The social practice of tomb spoliation in late antiquity (especially in the $4^{\text {th }}$ and $5^{\text {th }}$ centuries) can be compared with the simultaneous spoliation of the temples. As with the tombs, there seems to have been less restraint in reusing the property of the old gods than in earlier periods. ${ }^{74}$ Like the tombs, the spoliation of temples can therefore be explained with the need for decorative material for new buildings, rather than interpreted as ideologically motivated destruction. ${ }^{75}$ Furthermore, it is interesting to see that the edicts against tomb violation by the emperors (from the mid-fourth to the early $5^{\text {th }}$ century) were promulgated at the same time as edicts to protect pagan temples and their ornaments from private plundering. ${ }^{76}$ The emperors did not try to protect the old temples or old pagan tombs

\footnotetext{
${ }^{70}$ For example for the fortification walls and churches in North Africa see: Deichmann 1975, 64-91, 71-73.

${ }^{71}$ See above section II.

72 Tombs were an important resource for building and to enrich the public treasury at that point, see: Lafferty 2013,215 217.

${ }^{73}$ We might suggest that once the respect and fear from the old gods (the dis manes) who protected the tombs had vanished, there was less restraint in reusing material from the imperial tombs. Kaser 1978, 19.

${ }^{74}$ This viewpoint is very frequently overestimated when written sources alone are consulted, but archaeological evidence is neglected.

${ }^{75}$ See for example: Stewart 1999; Cadario 2013; Kristensen 2013; Pollini 2014.

${ }^{76}$ Kunderewicz 1971, 137-153.
} 
for ideological motives, rather they tried to stamp out the practice of private reuse of stone from temples and tombs because the well-preserved and unharmed material could be used for their own building purposes. Finally, an order by Theodoric to the saio Duda in 507-511 AD, as recorded in the Variae of Cassiodorus, characterises the extent to which tombs had become an important resource for the state by that time and how involved imperial authority had become in tomb robbing.

"It is the custom of prudence to reclaim treasures hidden in the earth for humane purposes, and to designate it for the business of the living and not the dead, since these buried items are of no use to Us and are of no advantage to the dead when left behind. The circulation of precious metals is certainly a comfort for men... Wherefore, by this just command We decree that you [i.e. Duda] proceed in public view to any place where valuable materials are said to be buried. And if any gold or silver should happen to be found through your investigation, you will faithfully vindicate it for the public treasury, but only under this condition: namely, that you abstain from laying your hands on the ashes of the dead, since We do not wish to seek gains that can be obtained through deadly sins. Buildings protect the ashes, and columns or marble adorn the sepulchres: Let not those who have left behind the cares of the living hold on to riches. It is right for gold to be taken from sepulchres where there is no master (dominus): Indeed, it is a kind of offense to leave behind hidden treasures for the dead, through which the life of the living can sustain itself. It is not greed to take away that for which there is no master to lament the loss of. "77

Cristina Murer

Freie Universität Berlin

cristina.e.murer@gmail.com

\footnotetext{
${ }^{77}$ Cassiodorus, Variae 4,34: "Prudentiae mos est in humanos usus terris abdita talenta revocare commerciumque viventium non dicere mortuorum, quia et nobis infossa pereunt et illis in nullam partem profutura linquuntur. metallorum quippe ambitus solacia sunt hominum . . . Atque ideo moderata iussione decernimus, ut ad illum locum, in quo latere plurima suggeruntur, sub publica testificatione convenias: et si aurum, ut dicitur, vel argentum fuerit tua indagatione detectum, compendio publico fideliter vindicabis: ita tamen ut abstineatis manus a cineribus mortuorum, quia nolumus lucra quaeri, quae per funesta possunt scelera reperiri. aedificia tegant cineres, columnae vel marmora ornent sepulcra: talenta non teneant, qui vivendi commercia reliquerunt. Aurum enim sepulcris iuste detrahitur, ubi dominus non habetur: immo culpae genus est inutiliter abditis relinquere mortuorum, unde se vita potest sustentare viventium. non est enim cupiditas eripere, quae nullus se dominus ingemiscat amisisse." Translation by Lafferty 2013, 215.
} 


\section{BIBLIOGRAPHY}

Antonelli, F., Santi, P., Renzulli, A., Santoro Bianchi, S. 2016: "The Architectural Reuse of Roman Marble and Stone Spolia in the Early Medieval Monte Sorbo Church (Sarsina, Central Italy)", Archaeometry 58, 353-370.

Azzara, S. 2002: “Osservazioni sul senso delle rovine nella cultura antica", ASNP 4.14, 1-12.

Baldassarre, I. 1988: "La necropoli dell'Isola Sacra (Porto)", in H. von Hesberg, P. Zanker (eds.), Römische Gräberstraßen: Selbstdarstellung, Status, Standard. Kolloquium in München vom 28.- 30. Oktober 1985. Veröffentlichungen der Kommission zur Erforschung des antiken Städtewesens, München, $125-138$

Becatti, G. 1948: Case Ostiensi del tardo impero, Roma.

Becatti, G. 1961: Mosaici e pavimenti marmorei (Scavi di Ostia 4.2), Roma.

Behrends, O. 1978: "Grabraub und Grabfrevel im römischen Recht", in H. Jankuhn (ed.), Zum Grabfrevel in vor- und frühgeschichtlicher Zeit: Untersuchungen zu Grabraub und "haugbrot" in Mittel- und Nordeuropa; Bericht über ein Kolloquium d. Komm. für d. Altertumskunde Mittelu. Nordeuropas vom 14. bis 16. Febr. 1977 (Abhandlungen der Akademie der Wissenschaften in Göttingen, Philologisch-Historische Klasse 3), Göttingen, 85-106.

Bell, M. 1998: “Le stele greche dell'Esquilino e il cimitero di Mecenate", in M. Cima, E. La Rocca (eds.), Horti romani. Atti del convegno internazionale, Roma 4 - 6 maggio 1995, Roma, 295-314.

Bierbrauer, V. 1975: Die ostgotischen Grab- und Schatzfunde in Italien (Biblioteca degli Studi medievali 7), Spoleto.

Boersma, J.S. 1985: Amoenissima civitas: block V.II at Ostia. Description and analysis of its visible remains, Assen.

Bolla, M. 2015: "Sepoltura non perpetua: la riapertura delle tombe e il caso concordiese", in F. Rinaldi, A. Vigoni (eds.), Le necropoli della media e tarda età imperiale (III-IV secolo D.C.) a Iulia Concordia e nell'arco altoadriatico. Organizzazione spaziale, aspetti monumentali e strutture sociali. Atti del convegno di studio a Concordia Sagittaria, 5-6 giugno 2014
(Archeologia del Veneto 4), Concordia Sagittaria, 357-378.

Borg, B. 2013: Crisis and ambition: tombs and burial customs in third-century CE Rome, Oxford.

Cadario, M. 2013: "La destruction délibérée des statues pour des raisons politiques dans le monde romain", in J. Driessen (ed.), Destruction: Archaeological, Philological and Historical Perspectives, Louvain, 415-433.

Calza, G. 1940: La necropoli del Porto di Roma nell 'isola Sacra, Roma.

Calza, R. 1978: Ostia I ritratti. Ritratti romani dal 160 circa alla metà del III secolo d.C (Scavi di Ostia 9,2), Roma.

Camilli, S. 1831:"Contorni archeografici di Viterbo", BdI 1, 201-202.

Cantino Wataghin, G. 1986: "Archeologia e archeologie. Il rapporto con l'antico fra mito, arte e ricerca", in S. Settis (ed.), Memoria dell'antico nell'arte italiana, 1. L'uso dei classici, Turin, 169. 217.

Carroll, M. 2006: Spirits of the dead: Roman funerary commemoration in western Europe, Oxford.

Cartron, I.H., Fabrice Scuiller, C. (eds.) 2015: Les sarcophages de l'Antiquité tardive et du haut Moyen Âge: fabrication, utilisation, diffusion: actualité de l'archéologie en Aquitaine et Midi-Pyrénées: actes des XXXe Journées Internationales d'Archéologie Mérovingienne, Musée d'Aquitaine, Bordeaux, 2 - 4 octobre 2009, Bordeaux.

Coates-Stephens, R. 2002: "Epigraphy as spolia. The reuse of inscriptions in early medieval buildings", BSR 70, 275-296.

Coates-Stephens, R. 2012: "The Walls of Aurelian", in R. Behrwald, C. Witschel (eds.), Rom in der Spätantike (Heidelberger althistorische Beiträge und epigraphische Studien 51), Stuttgart, 83-110.

Colonna, G. 1975: "Viterbo. Tegola bollata dalle Terme del Bacucco", NSA 29, 43-45.

Cozza, L. 1983: "Le tegole di marmo del Pantheon", in K. De Fine Licht (ed.), Città e architettura nella Roma imperiale. Atti del seminario del 27 ottobre 1981 nel $25^{\circ}$ anniversario dell'Accademia di Danimarca, Roma, 109-118.

Crawford, M.H. (ed.) 1996: Roman statutes. (Bulletin of the Institute of Classical Studies. Supplement), 2 vols, London.

Creaghan, S.J. 1951: Violatio Sepulcri: An Epigraphical Study, Princeton PhD. 
David, M. 2013: "Nuovi dati e argomenti per Ostia tardoantica dal Progetto Ostia Marina”, MEFRA 126, 173-186.

Deichmann, F.W. 1975: Die Spolien in der spätantiken Architektur (Sitzungsberichte der Bayerischen Akademie der Wissenschaften, PhilosophischPhilologische und Historische Klasse 6), München.

Despinēs, G., Stephanidou-Tiveriou, T., Voutyras, E. 1997: Catalogue of sculpture in the Archaeological Museum of Thessaloniki, Thessaloniki.

Esch, A. 2005: Wiederverwendung von Antike im Mittelalter. Die Sicht des Archäologen und die Sicht des Historikers (Hans-Lietzmann-Vorlesungen 7), Berlin.

Esch, A. 2011: “Antike Mauer im Mittelalter", in J. Fried, O. Rader (eds.), Welt des Mittelalters. Erinnerungsorte eines Jahrtausends, München, 8599.

Fabricius Hansen, M. 2013: "The Use of Spolia in Early Christian and Medieval Churches: Possibilities of Interpretation", in S. Altekamp, C. MarcksJacobs, P. Seiler (eds.), Perspektiven der Spolienforschung. Spoliierung und Transposition 1, Berlin, 85-96.

Fabricius Hansen, M. 2015: The spolia churches of Rome: recycling Antiquity in the Middle Ages, Aarhus.

Fejfer, J. 2008: Roman portraits in context (Image and context 2), Berlin.

Ganzert, J. 1981: "Einige Beobachtungen am Thermensaal von Bacucco bei Viterbo", $A A$, 131-142.

Gatti, E. 1925: "Notizie di recenti trovamenti di antichità in Roma e nel suburbio", BCom 53, 271304.

Gering, A. 2011a: "Das Stadtzentrum von Ostia in der Spätantike. Vorbericht zu den Ausgrabungen 20082011", RM 117, 409-509.

Gering, A. 2011b: "Krise, Kontinuität, Auflassung und Aufschwung in Ostia seit der Mitte des 3. Jahrhunderts", in R. Schatzmann, S. Martin-Kilcher (eds.), Das römische Reich im Umbruch: Auswirkungen auf die Städte in der zweiten Hälfte des 3. Jahrhunderts. Internationales Kolloquium, Bern/Augst, 3.-5. Dezember 2009, Montagnac, 301316.

Girardi Jurkić, V. 2011: "Roman Spolia from Necropolises and their Reuse for Reinforcing late Antique City Walls and for Building Edifices of the Modern Era in Pula", Hortus artium medievalium. Journal of the International Research Center for Late Antiquity and Middle Ages 17, 23-28.

Greenhalgh, M. 1989: The survival of Roman antiquities in the Middle Ages, London.
Guidobaldi, F. 1999: "Le domus tardoantiche di Roma come sensori delle trasformazioni culturali e sociali", in W.V. Harris, J. Arce (eds.), The transformations of urbs Roma in late antiquity (Journal of Roman archaeology. Supplementary series 33), Portsmouth, 53-68.

Guidobaldi, F. 2007: "Una domus tardoantica e la sua trasformazione in chiesa dei SS. Quirico e Giulitta", in A. Leone, D. Palombi, S. Walker, E.M. Steinby (eds.), Res Bene Gestae: ricerche di storia urbana su Roma antica in onore di Eva Margareta Steinby (Lexicon topographicum urbis Romae, Supplementum 4), Roma, 55-78.

Hallett, C.H. 2005: The Roman nude: heroic portrait statuary $200 B C-A D 300$, Oxford.

Hamilton, H.C., Falconer, W. 1856: The geography of Strabo. Literally translated, with notes. Volume II, London.

Hay, S., Keay, S.J., Millett, M. 2012: “Teano (Teanum Sidicinum), Campania”, in F.M.R. Vermeulen (ed.), Urban landscape survey in Italy and the Mediterranean Oxford, 105-113.

Heinzelmann, M. 2000: Die Nekropolen von Ostia: Untersuchungen zu den Gräberstraßen vor der Porta Romana und an der Via Laurentina (Studien zur antiken Stadt 6), München.

Himmelmann, N. 1989: Herrscher und Athlet: die Bronzen vom Quirinal. Bonn, Akademisches Kunstmuseum, 20. Juni - 5. September 1989, Milano.

Huskinson, J. 2015: Roman strigillated sarcophagi : art and social history, Oxford.

Insalaco, A. 2005: La città dell'acqua: archeologia sotteranea a Fontana di Trevi, Milano.

Jäggi, C. 2013: "Spolien in Ravenna - Spolien aus Ravenna: Transformation einer Stadt von der Antike bis in die frühe Neuzeit", in S. Altekamp, C. MarcksJacobs, P. Seiler (eds.), Perspektiven der Spolienforschung. Spoliierung und Transposition 1, Berlin, 287-330.

Jankuhn, H. (ed.) 1978: Zum Grabfrevel in vor- und frühgeschichtlicher Zeit: Untersuchungen zu Grabraub und "haugbrot" in Mittel- und Nordeuropa; Bericht über ein Kolloquium d. Komm. für d. Altertumskunde Mittel- u. Nordeuropas vom 14. bis 16. Febr. 1977. (Abhandlungen der Akademie der Wissenschaften in Göttingen, PhilologischHistorische Klasse (3), Göttingen.

Jucker, H. 1966: "Die Behauptung des Balbinus", $A A$ 81, 501-514.

Kaser, M. 1978: “Zum römischen Grabrecht”, ZRG 95, 15-92.

Klevnäs, A.M. 2013: Whodunnit? Grave robbery in Anglo-Saxon England and the Merovingian kingdoms (BAR international series 2582), Oxford. 
Klingenberg, A. 1983: "Grabrecht”, RAC 12, 590-636.

Koch, G. 1994: "Christliche Wiederverwendung attischer Sarkophage”, Boreas 17, 115-120.

Kristensen, T.M. 2013: Making and breaking the gods: christian responses to pagan sculpture in late antiquity (Aarhus Studies in Mediterranean Antiquity 12), Aarhus.

Kümmel, C. 2009: Ur- und frühgeschichtlicher Grabraub. Archäologische Interpretation und kulturanthropologische Erklärung (Tübinger Schriften zur ur- und frühgeschichtlichen Archäologie 9), Münster.

Kunderewicz, C. 1971: "La protection des monuments d'architecture antique dans le Code Théodosien", in Studi in onore di Edoardo Volterra 4 (Pubblicazioni della Facoltà di giurisprudenza dell'Università di Roma 45), Milano, 137-153.

Lafferty, S.D.W. 2013: Law and society in the age of Theoderic the Great: a study of the Edictum Theoderici, Cambridge.

Lafferty, S.D.W. 2014: "Ad sanctitatem mortuorum: tomb raiders, body snatchers and relic hunters in late antiquity", EME 22, 3, 249-279.

Laird, M.L. 2000: "Reconsidering the so-called "Sede degli Augustali" at Ostia", MAAR 45, 41-84.

Lamm, S. 2015: "Grabbrauch Grabraub", in C. Bachhiesel, M. Handy (eds.), Kriminalität, Kriminologie und Altertum (Antike Kultur und Geschichte 17), Wien, 163-186.

Lanciani, R.A. 1899: The destruction of ancient Rome: a sketch of the history of the monuments, New York.

Lanciani, R.A. 1990: Forma urbis Romae, Roma.

Lenzi, P. 1998: "Sita in loco qui vocatur calcaria: attività di spoliazione e forni da calce a Ostia", $A M$ 25, 247-263.

Lo Monaco, A. 2011: "Algide e belle come dee: Immagini private e apoteosi a Roma in età medioimperiale", in E. La Rocca, C. Parisi Presicce, A. Lo Monaco (eds.), Ritratti: le tante facce del potere, Roma, 335-357.

Machado, C. 2012: "Aristocratic Houses and the Making of Late Antique Rome and Constantinople", in L. Grig, G. Kelly (eds.), Two Romes: Rome and Constantinople in late antiquity, Oxford, 136-158.

Maderna, C. 1988: Iuppiter Diomedes und Merkur als Vorbilder für römische Bildnisstatuen: Untersuchungen zum römischen statuarischen Idealporträt (Archäologie und Geschichte 1), Heidelberg.

Marinucci, A. 2012: Disiecta membra: iscrizioni latine da Ostia e Porto 1981-2009, Roma.

Messina, A. 2005: "Il riuso di sarcofagi romani per le reliquie dei martiri della tradizione tergestina", in G. Cuscito (ed.), San Giusto e la tradizione martiriale tergestina: nel XVII centenario del martirio di San
Giusto e per il Giubileo d'oro sacerdotale di Eugenio Ravignani Vescovo di Trieste (Antichità altoadriatiche 60), 185-196.

Milioni, A. 2014: Le terme romane di Viterbo: guida archeologica, Viterbo.

Mommsen, T. 1895: "Zum römischen Grabrecht", ZRG 16, 212-220.

Mommsen, T. 1899: Römisches Strafrecht (Systematisches Handbuch der deutschen Rechtswissenschaft 1,4), Leipzig.

Munro, B. 2016: "Sculptural Deposition and Lime Kilns at Roman Villas in Italy and the Western Provinces in Late Antiquity", in T. Myrup Kristensen, L.M. Stirling (eds.), The Afterlife of Greek and Roman Sculpture. Late Antique Responses and Practices, Ann Arbor, 47-68.

Murer, C. 2016: "The Reuse of Funerary Statues in Late Antique Prestige Buildings at Ostia", in T. Myrup Kristensen, L.M. Stirling (eds.), The Afterlife of Greek and Roman Sculpture. Late Antique Responses and Practices, Ann Arbor, 177-196.

Pavolini, C. 2011: "Un gruppo di ricche case ostiensi del Tardo Impero. Trasformazioni architettoniche e cambiamenti sociali", in O. Brandt, P. Pergola (eds.), Marmoribus vestita. Studi in onore di Federico Guidobaldi (Studi di antichità cristiana 62), Rom, 1025-1048

Pavolini, C. 2013: "Rileggendo le domus delle Colonne e dei Pesci", MEFR 126, 147-160.

Pensabene, P. 2007: Ostiensium marmorum decus et decor: studi architettonici, decorativi e archeometrici (Studi miscellanei 33), Roma.

Pensabene, P. 2015: Roma su Roma: reimpiego architettonico, recupero dell'Antico e trasformazioni urbane tra il IIIe il XIII secolo (Monumenti di antichità cristiana II,22), Città del Vaticano.

Pensabene, P., Panella, C. 1993-1994: "Reimpiego e progettazione architettonica nei monumenti tardoantichi di Roma 1", RAL 66, 111-283.

Pfuhl, E., Möbius, H. 1977: Die ostgriechischen Grabreliefs, Mainz.

Pharr, C. 1952: The Theodosian code and novels, and the Sirmondian constitutions (The Corpus of Roman law. Corpus juris Romani 1), Princeton.

Pollini, J. 2014: "The archaeology of destruction. Christians, images of classical antiquity, and some problems of interpretation", in S. Ralph (ed.), The archaeology of violence. Interdisciplinary approaches (IEMA proceedings 2), Albany, 241270.

Porcari, B. 2009: "Dai monumenti funerari alle calcare. Storia di un contesto di materiali lapidei dal Trastevere (Roma)", RM 115, 93-129. 
Potter, T.W., 1993, “The Mola di Monte Gelato. A microcosm of the history of Roman and early medieval Rome?" in L. Paroli, P. Delogu (eds.), La storia economica di Roma nell'alto medioevo alla luce de $i$ recenti scavi archeologici. Atti del Seminario, Roma 2-3 aprile 1992, Firenze, 137-152.

Potter, T.W., King, A.C. 1988: "Scavi a Mola di Monte Gelato presso Mazzano Romano, Etruria Meridionale. Primo rapporto preliminare", Archeologia medievale: cultura materiale, insediamenti, territorio 15, 253-311.

Potter, T.W., King, A.C., Allason-Jones, L., Cartwright, C. 1997: Excavations at the Mola di Monte Gelato: a Roman and medieval settlement in South Etruria (Archaeological monographs of the British School at Rome 11), London.

Rebillard, E. 2003: "The cult of the dead in late antiquity. Towards a new definition of the relation between the living and the dead", AAAH 17, 47-55.

Rebillard, E. 2009: The Care of the Dead in Late Antiquity (Cornell Studies in Classical Philology 59), Ithaka.

Saguì, L., Coletti, C.M. 2004: "Contesti tardoantichi dall'area a S-E della Crypta Balbi”, in L. Paroli, C.M. Coletti (eds.), Roma dall'antichità al medioevo, 2. Contesti tardoantichi e altomedievali, Milano, 242277.

Schmölder-Veit, A. 2000: "Öffentliche Brunnen und Nymphäen in Ostia”, in G.C.M. Jansen (ed.), Cura Aquarum in Sicilia. Proceedings of the Tenth International Congress on the History of Water Management and Hydraulic Engineering in the Mediterranean Region in Syracuse, May 1998 (BABesch Suppl. 6), Leiden, 255-263.

Schnapp, A. 2011: Die Entdeckung der Vergangenheit: Ursprünge und Abenteuer der Archäologie, Stuttgart.

Settis, S., Andreae, B. (eds.) 1984: Colloquio sul reimpiego dei sarcofagi romani nel Medioevo: Pisa 5.-12. September 1982 (Marburger WinckelmannProgramm), Marburg/Lahn.

Sirano, F. 2011: Il teatro di Teanum Sidicinum: dall'antichità alla Madonna delle Grotte, Cava de' Tirreni.

Sirano, F., Balasco, A., Beste, H.-J., D’Avino, V., Neudecker, R. 2002: "Il teatro di Teanum Sidicinum. Attraverso un progetto di rivalutazione", RM 109, 317-336.

Sirano, F., Beste, H.-J. 2006: "Studi sul teatro di Teano. Rassegna preliminare", $R M$ 112, 399-422.

Stewart, A. 1999: "The destruction of statues in late antiquity", in R. Miles (ed.), Constructing identities in late antiquity, London, 159-189.
Strothmann, M. 2006: "Hausfriedensbruch im Totenreich. Gewalt gegen Gräber im römischen Reich", in L.M. Günther, M. Oberweis (eds.), Inszenierungen des Todes, Hinrichtung - Martyrium - Leichenschändung, Bochum, 1-20.

Tantillo, I., La Rocca, C. 2017: "Corredi, corpi e reliquie nelle Variae di Cassiodoro. La competizione tra re e vescovi per le risorse del sottosuolo", in V. Lore, G. Bührer-Thierry, R. Le Jan (eds.), Acquérir, prélever, contrôler: les ressources en compétition (400-1100), Leiden, 21-42.

Underwood, D. 2015: "Reuse as archaeology in Ostia: a test case for late antique building chronologies in Ostia”, in L. Lavan, Mulryan M. (eds.), Field methods and post-excavation techniques in late antique archaeology, Leiden, 383-409.

Verkerk, D. 2007: "Life after death: The afterlife of sarcophagi in Medieval Rome and Ravenna", in C. Neuman de Vegvar, Ó.É. Carragáin (eds.), Roma Felix: Formation and reflections of Medieval Rome, Aldershot, 81-96.

Volp, U. 2002: Tod und Ritual in den christlichen Gemeinden der Antike (Supplements to Vigiliae Christianae, 65), Leiden, Boston.

Ward-Perkins, B. 1984: From classical antiquity to the Middle Ages: urban public building in northern and central Italy, AD 300-850, Oxford.

Wickert, L. 1933: Inscriptiones Latii veteris Latinae. Supplementum Ostiense, Fasc. 2, Indices topographicos. Corpvs inscriptionum Latinarum, Berlin.

Wrede, H. 1981: Consecratio in formam deorum: vergöttlichte Privatpersonen in der römischen Kaiserzeit, Mainz am Rhein.

Zanker, P., Ewald B.C. 2004: Mit Mythen leben: die Bilderwelt der römischen Sarkophage, München. 


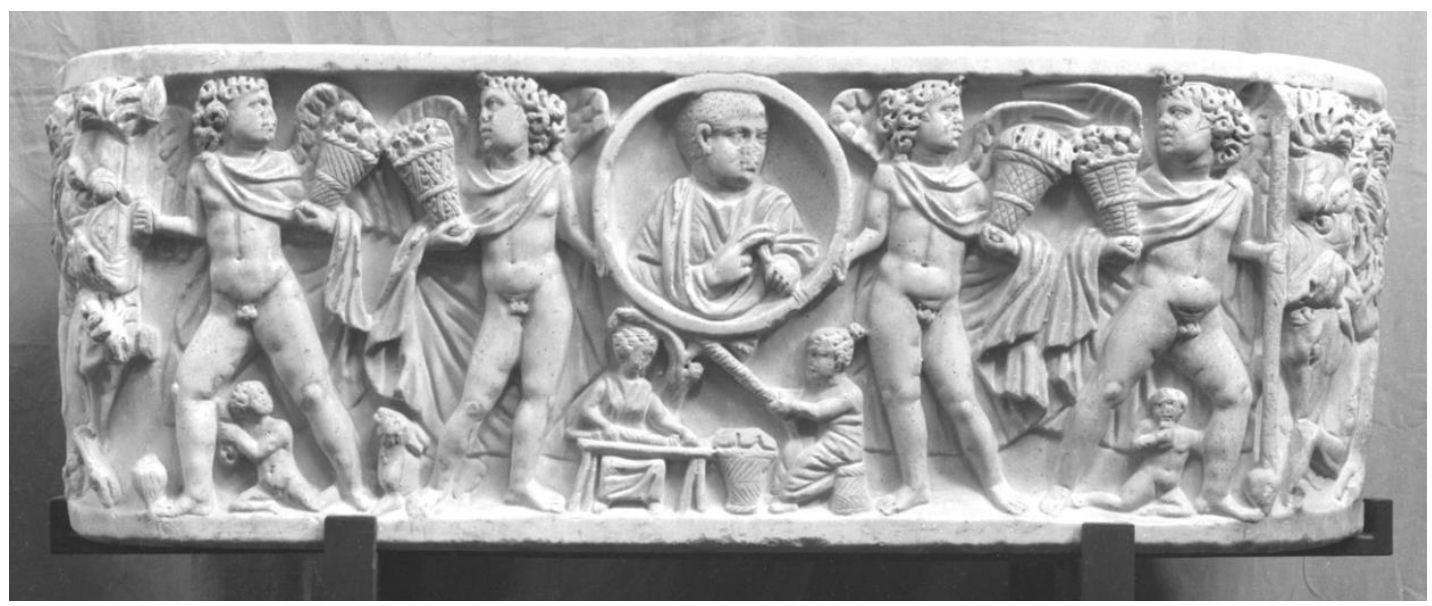

FIG. 1 - Roman sarcophagus reused as baptismal font in the Cathedral of Agrigento. Photo: Deutsches Archäologisches Institut.
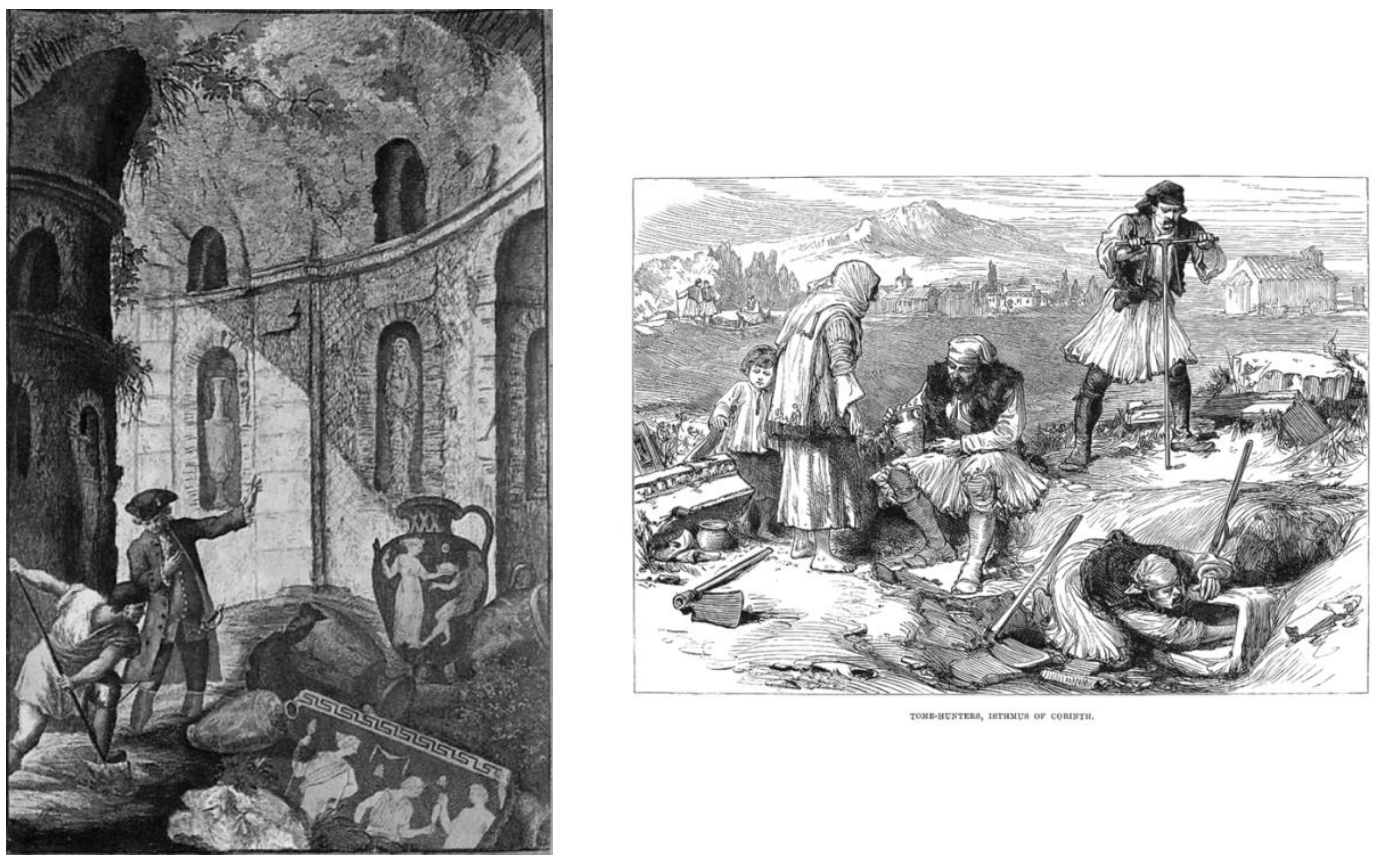

Fig. 2 - A Collector in a tomb at the Via Appia $\left(18^{\text {th }}\right.$ century).

FIG. 3 - Tomb hunters in Corinth $\left(19^{\text {th }}\right.$ century $)$. 
Mola di M. Gelato 1986-90
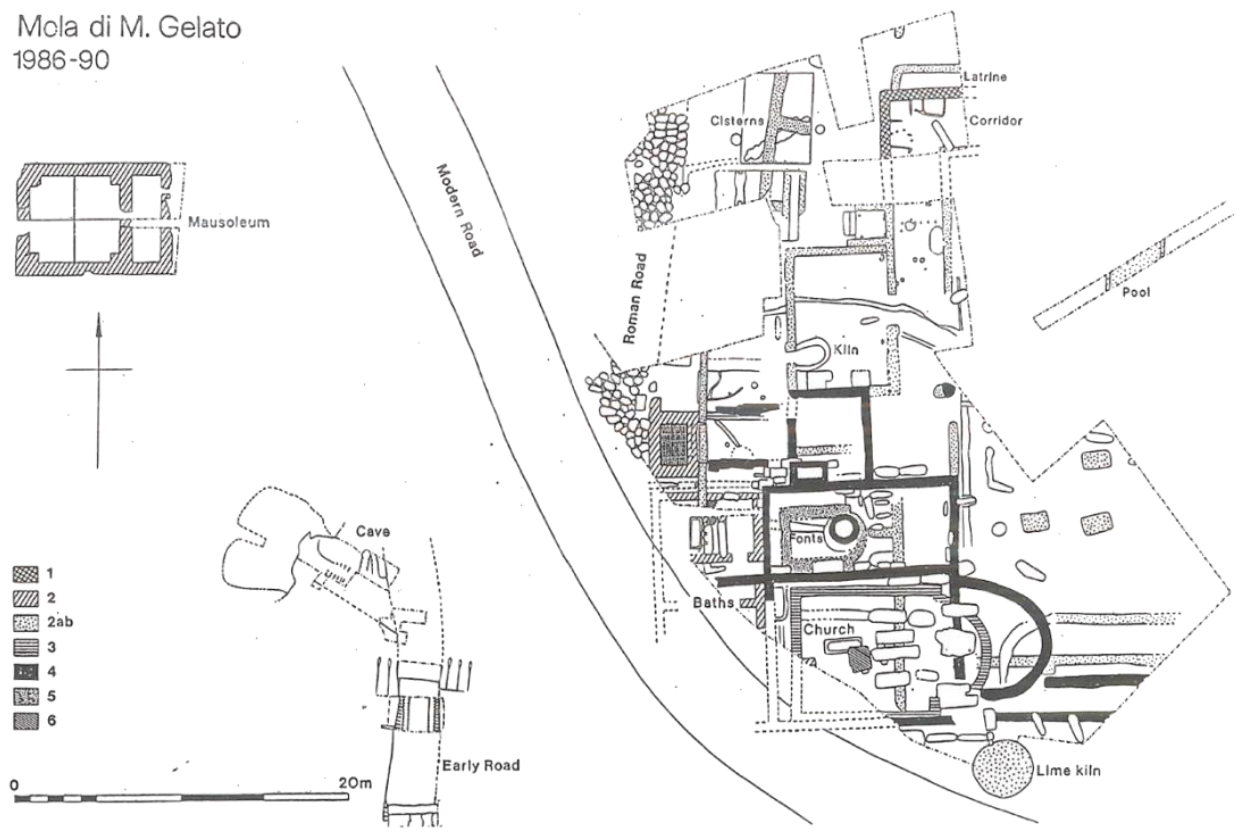

FIG. 4 - Mola di Monte Gelato, the occupation phases 1-6 (after Potter 1993, 142 fig. 3).

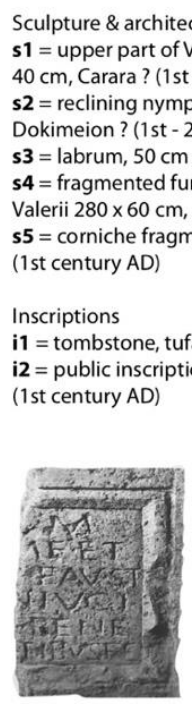

i1

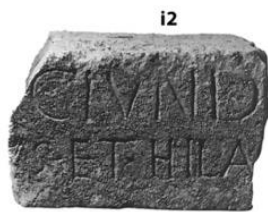

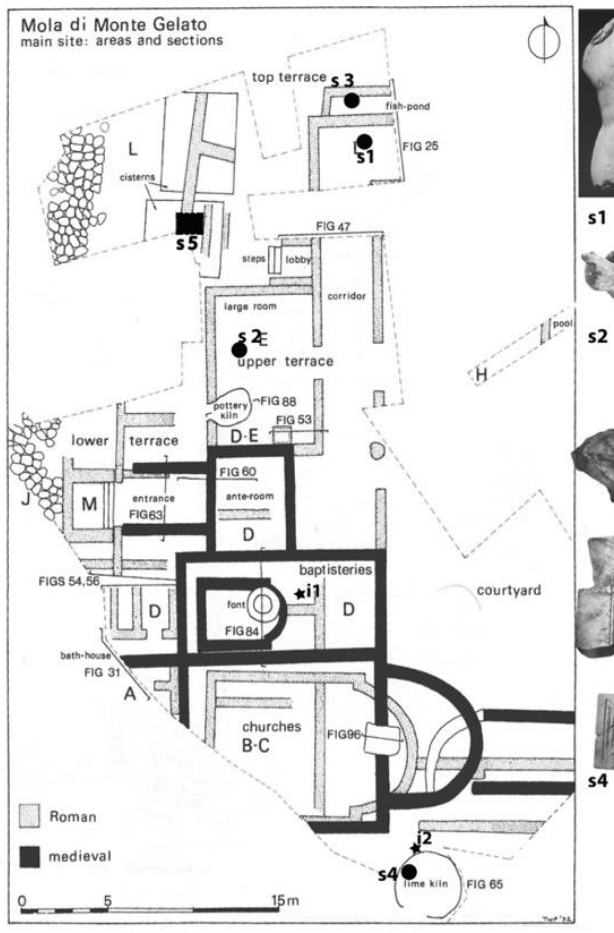

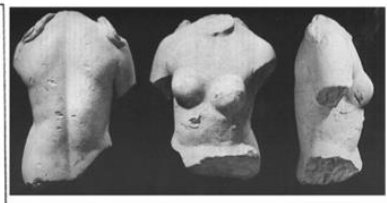

s2
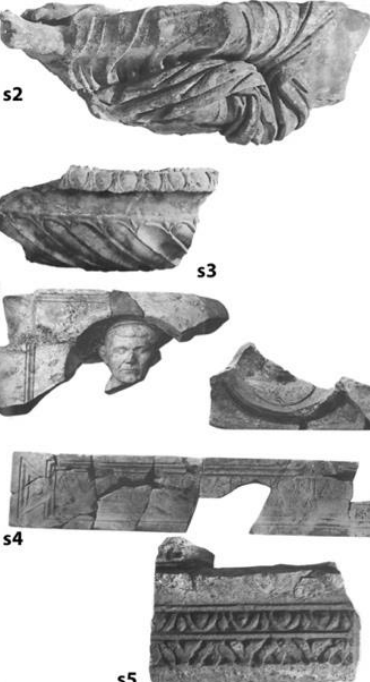

FIG. 5 - Late antique distribution of funerary material in the Villa at the Mola di Monte Gelato (author after Potter et al. 1997). 
Reused inscriptions for late antique floor pavments in Ostia

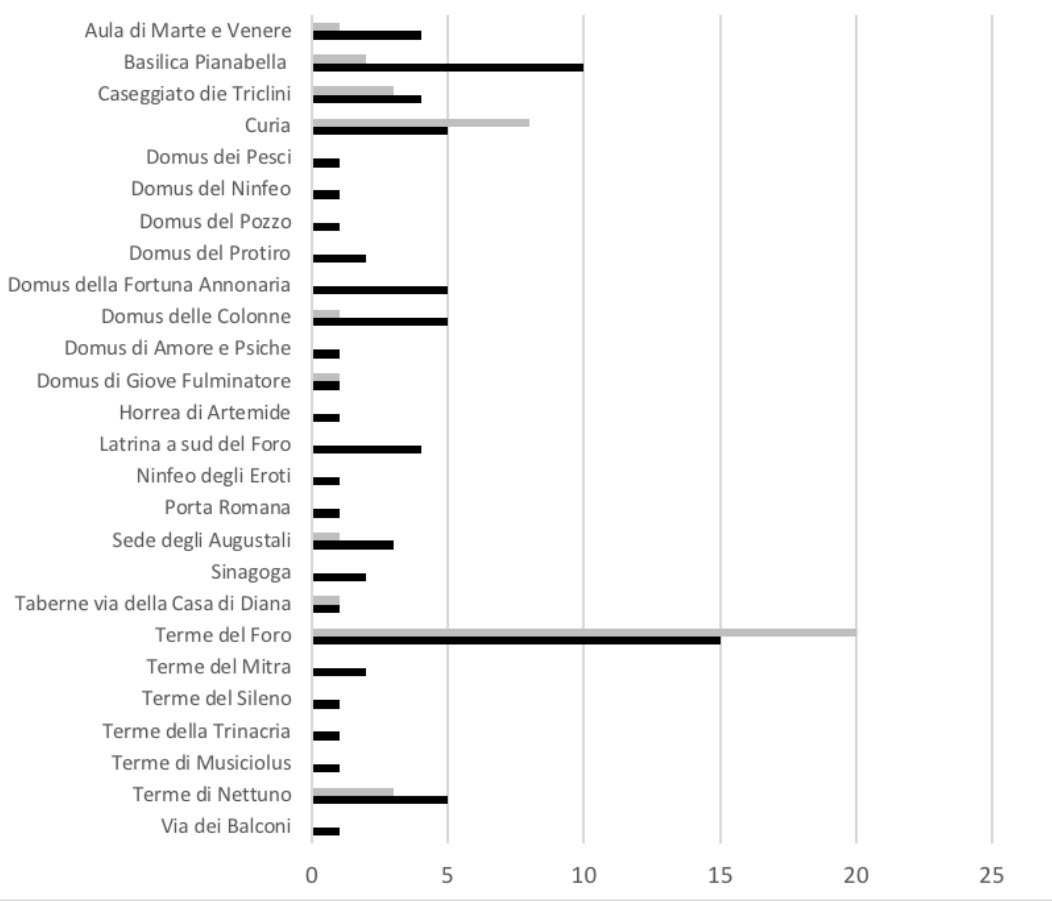

FIG. 6 - Funerary inscriptions (black) and other inscription categories (grey) reused in late antique buildings in Ostia (author after Pensabene 2007: 441-451).

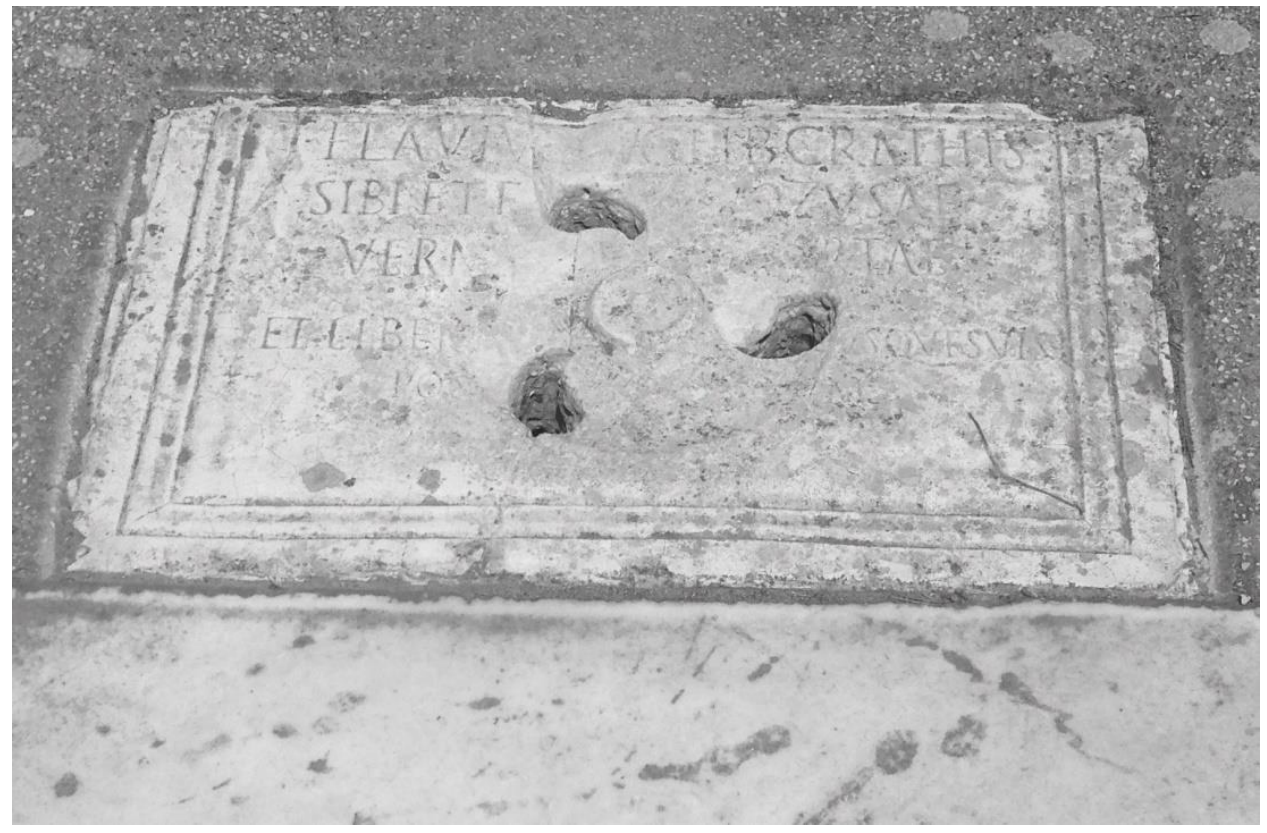

FIG. 7 - Reused funerary epitaph as drainage-pit in the Vestibule of the Domus del Protiro. 


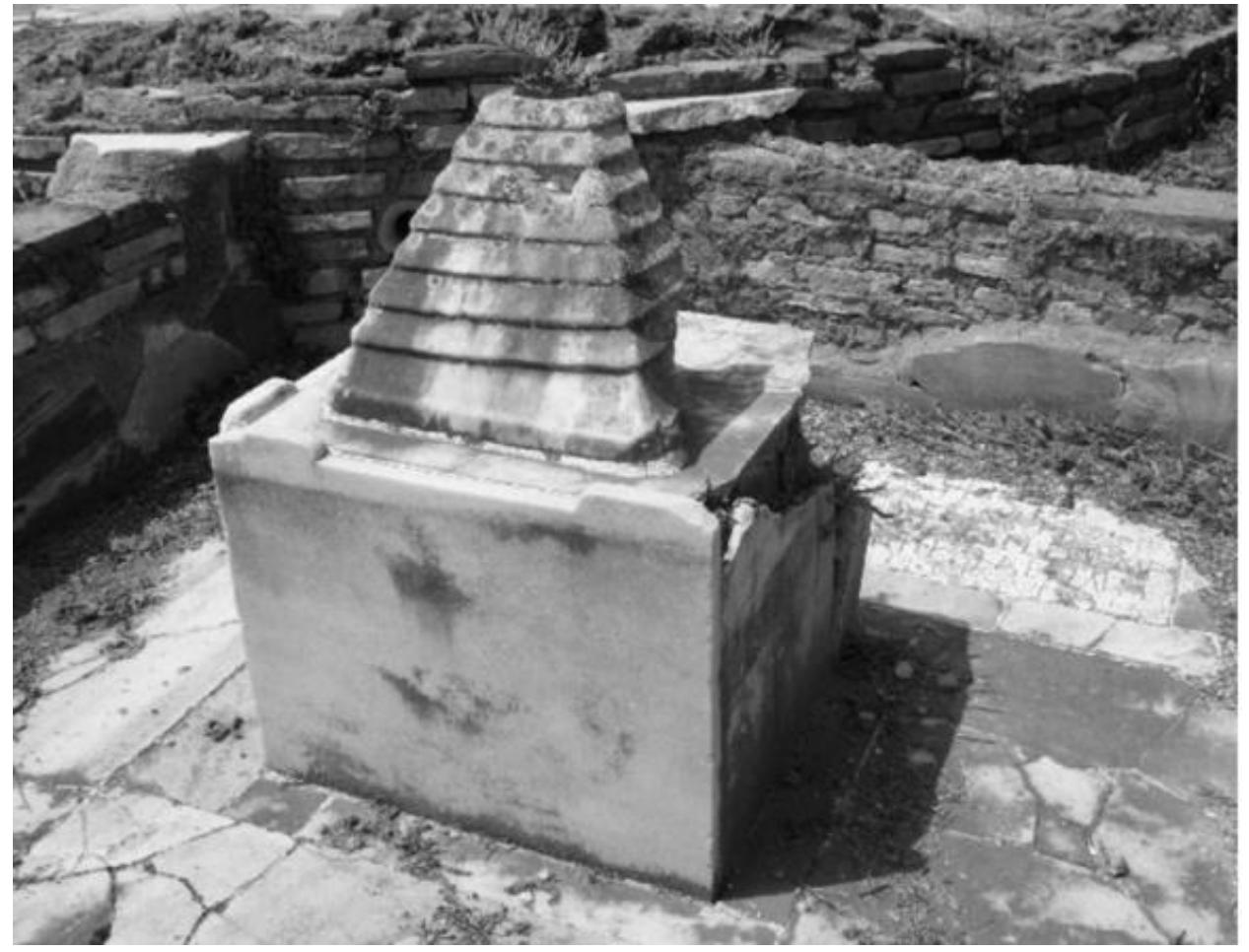

FIG. 8 - Reused funerary epitaph for the paving of the fountain of the Domus dei Pesci.

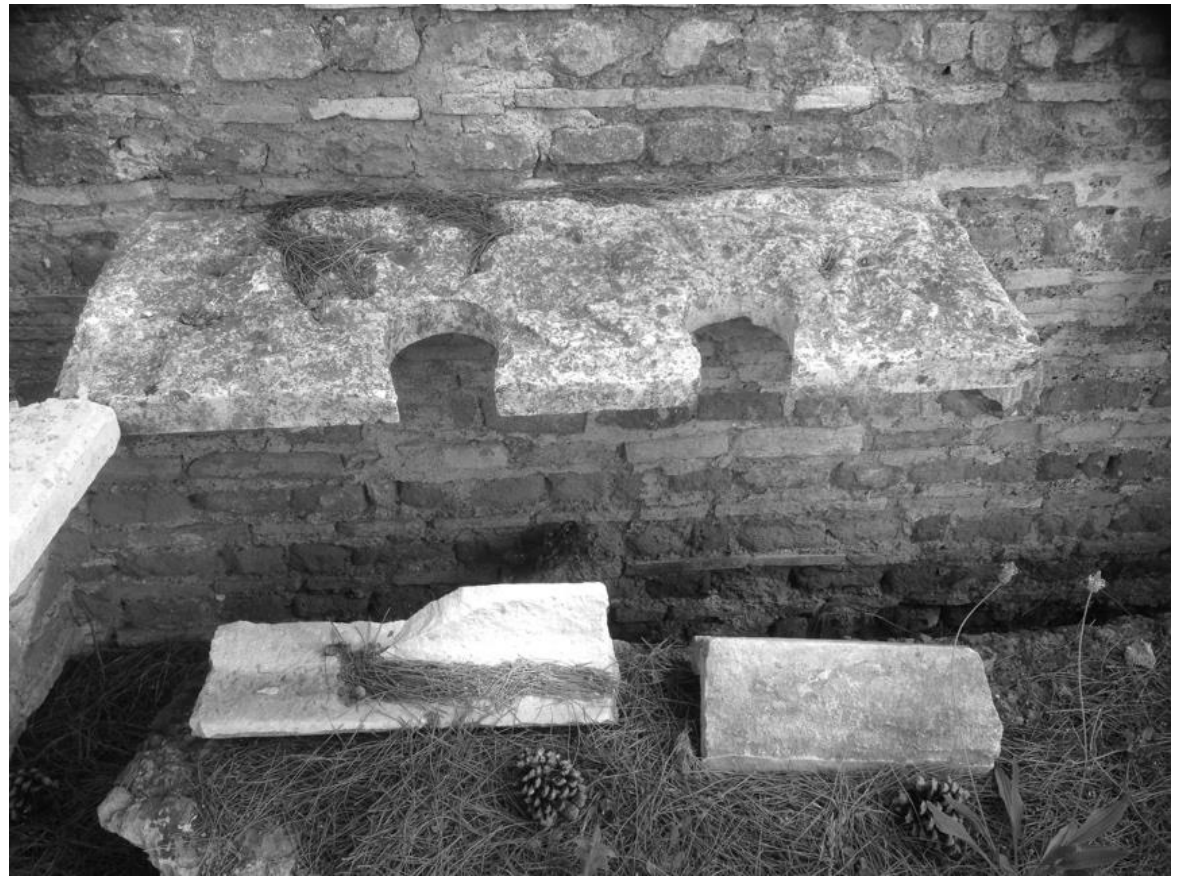

FIG. 9 - Sarcophagus relief reused as latrine bench in the so-called Forum latrine in Ostia (photo author). 


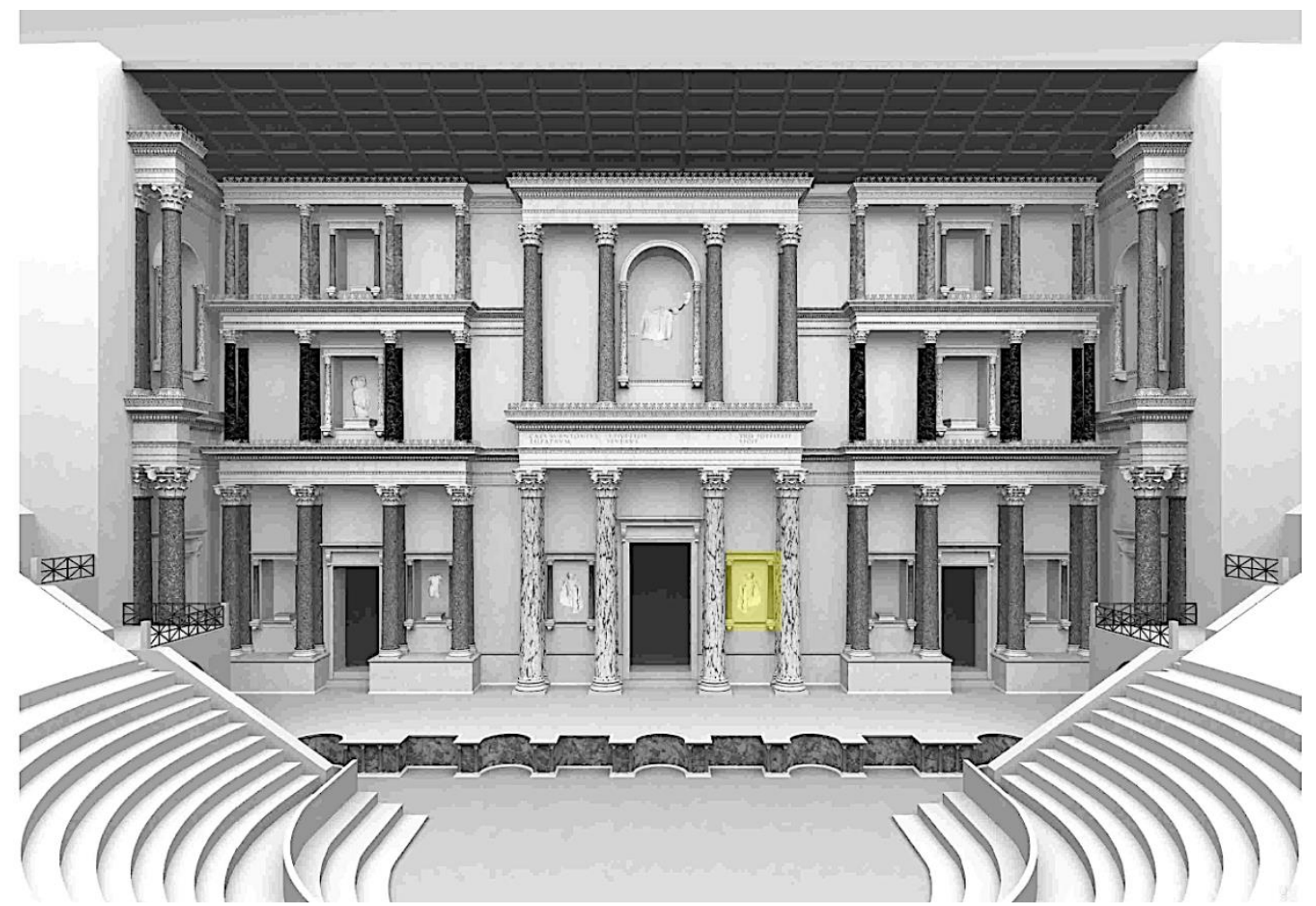

FIG. 10 - Reconstruction of the scaenae frons of the theatre in Teanum (after Sirano 2011, 36 fig. 7).

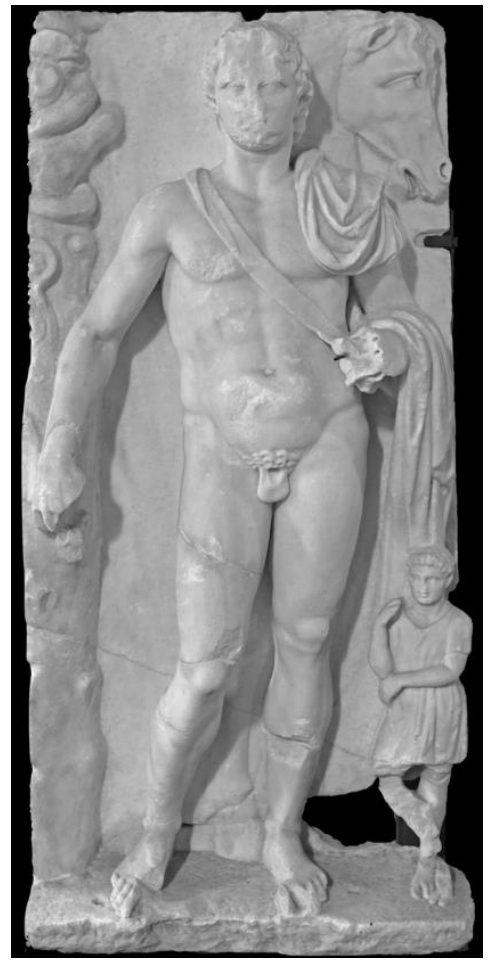

FIG. 11 - Late Hellenistic funerary relief re-used in the scaenae frons of the theatre in Teanum (after Sirano 2011, 112 fig. 15). 
Fig. 12 - Bacucco bath (near Viterbo) with octagonal hall.
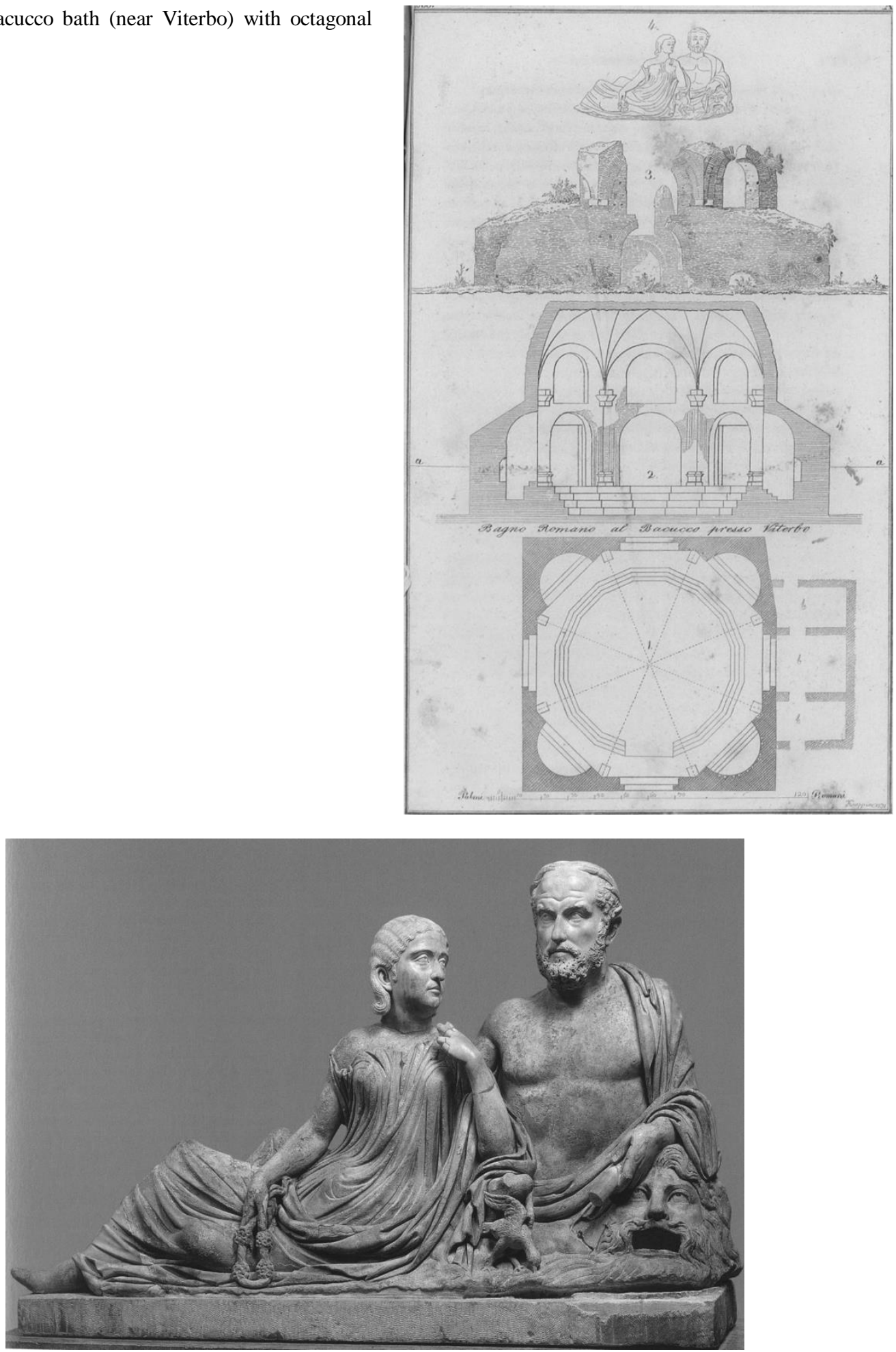

FIG. 13 - Fountain figure from the Bacucco bath (Paris, Louvre Inv. Ma 351; after Zanker and Ewald 2004,199 fig. 179). 


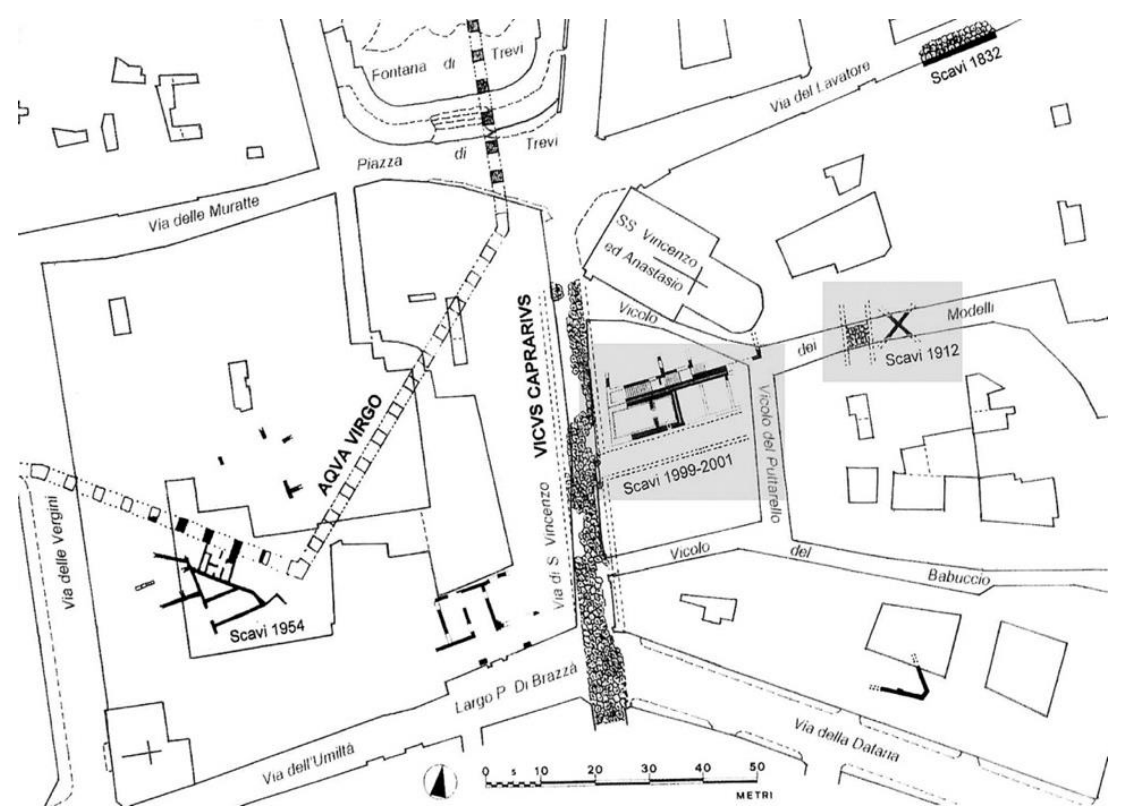

FIG. 14 - Rome, Regio VII (via Lata), excavations in 1912 and 1999-2000 (after Isalaco 2005, fig. 11).

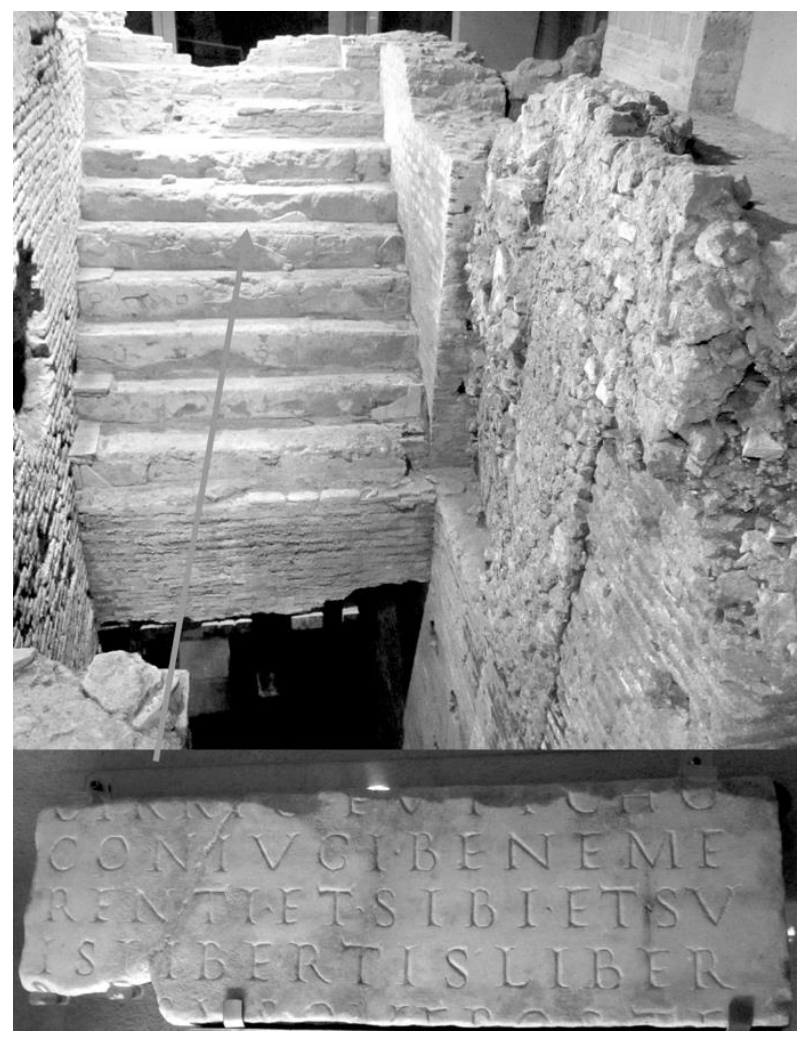

FIG. 15 - Domus at the Vicus Caprarius with visibly reused high imperial funerary epitaph for stairstep (photo author). 


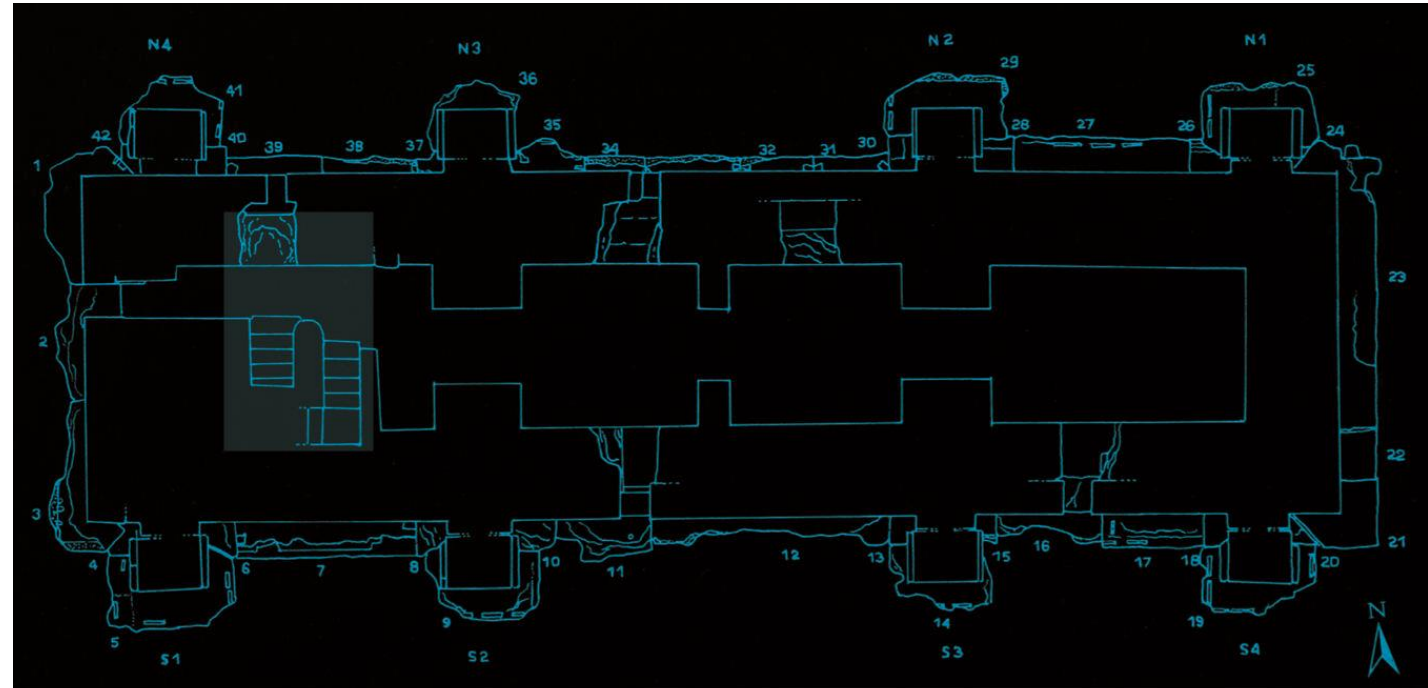

FIG. 16 - Arch of Constantine, interior small stair case leading to the attic and reused funerary inscriptions (author after Pensabene xx).

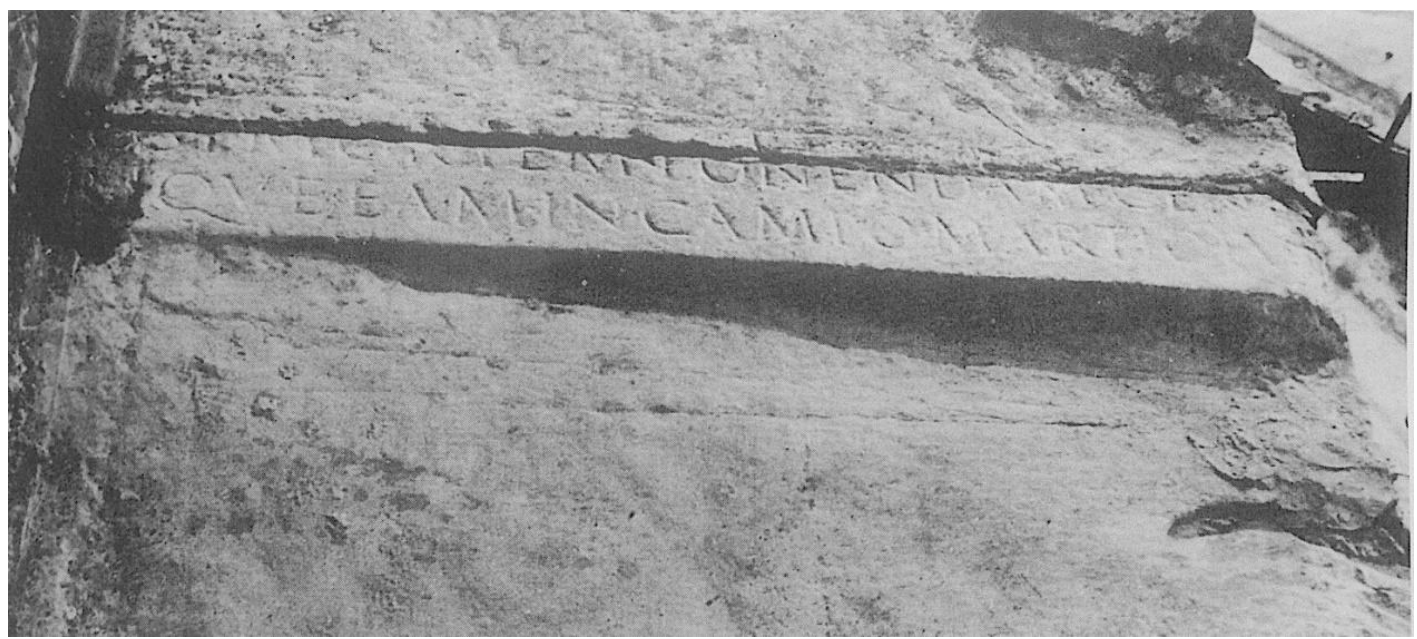

FIG. 17 - Late Republican funerary epitraph from Julia (?) reused as roof tile at the outer border of the Pantheon cupola (after Cozza 1983, 115 fig. 10). 
